\title{
The Influence of Salamanca in the Iberian Peninsula
}

\author{
The Case of the Faculties of Theology of Coimbra and Évora
}

\author{
Lidia Lanza and Marco Toste
}

\section{Introduction}

There is no doubt that Salamanca was the most important Iberian university in the $15^{\text {th }}$ and 16 th centuries and remained so even after the foundation of more than 20 universities in the Iberian Peninsula throughout those two centuries. ${ }^{1}$ There is also no doubt that the Salamancan faculties of theology and law were extraordinarily influential and played a major role in 16th-century thought. These are now common assumptions as a result of the scholarship of the last century. Yet this Salamancan-centred scholarship poses a serious problem: given the dearth of studies on how exactly Salamanca's thought influenced authors affiliated with other Iberian universities, how can we assume that Salamanca was indeed influential? We know so much about Salamanca's institutional setting and about its theological production - from the relectiones of Francisco de Vitoria, Melchor Cano, and Domingo de Soto, to the commentaries on Aquinas's Summa theologiae by Vitoria, Bartolomé de Medina, and Domingo Báñez - and yet we have little knowledge about the output and the teaching carried out in other Iberian universities. But is this lack of knowledge relevant? If we do not want to assume as a historical $a$ priori condition that, on the one hand, all the Iberian universities passively incorporated the views advanced by Vitoria and his fellow Salamancan professors and, on the other hand, that no Iberian university influenced Salamanca, the study of other universities appears as the only way to assess the influence of Salamanca and to grasp how that influence was exerted. In this regard, we are still extremely ignorant.

1 A table with the dates of the foundations of Iberian universities is found in Andrés Martín, Historia de la teología en España (1470-1570), 41-42, and Andrés Martín, "Las facultades de teología en las universidades españolas (1396-1868)", 321-322. See also the outline sketched in Pozo, "Origen e historia de las facultades de teología en las universidades españolas". 
The analysis of Salamanca's influence can be undertaken from two different perspectives: either by examining the career and output of students trained in Salamanca who went on to teach elsewhere, or by comparing a given university - its structure and production - with what happened in Salamanca and in this way assessing the similarities and differences between that university and Salamanca. In the wake of the pioneering studies of Beltrán de Heredia, it has been noted how some Iberian faculties of theology, such as Toledo, Sigüenza, Lleida, Oviedo, and Santiago de Compostela, were under the influence of Salamanca. ${ }^{2}$ Among the agents of this influence were the professors who received their theological training at Salamanca and then taught elsewhere, carrying with them the ideas (and in some cases the manuscripts) they had learned (and read) while in Salamanca. This is the case of Martín de Ledesma, who graduated from Salamanca and was then appointed to the vespers chair in Coimbra, taking with him texts of Vitoria and Soto. As Beltrán de Heredia has shown, Ledesma's printed commentary on Book IV of the Sentences is highly based on Vitoria's lectures and relectiones as well as on Soto's De iustitia et iure. ${ }^{3}$ Similarly, when Fernando Vellosillo became a professor at Sigüenza, he brought a manuscript of Soto's commentary on the $\mathrm{I}^{\mathrm{a}}-\mathrm{II}^{\text {ae }}$ and probably used it for his own lectures. ${ }^{4}$ But even in those cases in which we do not have evidence that students from Salamanca took manuscripts with them when they went to other universities, we can assume that whenever they went to other places, they helped spread the ideas they had been exposed to. This is notably the case of the Carmelite Bartolomé de Torres and of the Jesuit Francisco de Toledo: after studying under Vitoria, the former became a professor in Sigüenza in 1547 and produced one of the earliest printed commentaries on the Summa $(1567),{ }^{5}$ while the latter, after attending Soto's lectures, became a

2 Beltrán de Heredia, Miscelánea Beltrán de Heredia. Colección de artículos sobre historia de la teología española, especially the articles gathered in volume 4. See also Lanza and Toste, "The Sentences in Sixteenth-Century Iberian Scholasticism", 428-435 (together with the bibliography mentioned there) and the overview offered in Belda Plans, La Escuela de Salamanca y la renovación de la teología en el siglo $X V I, 827-852$.

3 See Beltrán de Heredia, "Las relecciones y lecturas de Francisco de Vitoria en su discípulo Martin de Ledesma, O.P.", 113-136.

4 See Toste, "The Commentaries on Aquinas's Summa Theologiae Ia-IIae, qq. 90-108 in Sixteenth-Century Salamanca: A Study of the Extant Manuscripts", 189-19o and Beltrán de Heredia, "La Facultad de Teología en la Universidad de Sigüenza", 47-5o.

5 See Llamas Martínez, Bartolomé de Torres: teólogo y obispo de Canarias. This scholar gives an example of a possible influence of Vitoria's teaching on Bartolomé de Torres's own lectures, see Llamas Martínez, Bartolomé de Torres: teólogo y obispo de Canarias, 70-71 n. 23. In his 
professor in the Roman College and lectured on the Summa between 1562 and $1569 .{ }^{6}$

Numerous other examples of this intense peregrinatio academica originating in (or related to) Salamanca could be adduced, such as Báñez, Tomás Manrique, Vicente Barrón, and Felipe Meneses. Nonetheless, the greater part of students and professors in Iberian universities had no direct relationship to Salamanca. If we really want to study the influence of Salamanca over other centres of learning, the second approach mentioned earlier, namely comparing Salamanca with other universities, appears more promising. The publication of numerous 16th-century Spanish university statutes along with the analysis of those statutes has already shown that many Spanish universities took the statutes of Salamanca as their model, whether entirely or partially. As has been shown elsewhere, throughout the 16th century, the Iberian universities came to adopt the great novelty that Vitoria introduced in the faculty of theology of Salamanca: the replacement of Peter Lombard's Sentences with Aquinas's Summa theologiae as the text that was to be read and commented on in the main chairs dedicated to scholastic theology. ${ }^{7}$ This shows that Salamanca had some influence on what happened elsewhere in the Iberian Peninsula. But we cannot infer from the fact that the Summa became the text that was used in the classroom in every Iberian faculty of theology that the same explanation works identically everywhere. In Salamanca, the Dominicans prevailed until the last decade of the 16th century and thus were able to impose Thomism, but the situation was different in other universities. For instance, Coimbra had a faculty composed of members of different religious orders, and although, as we will see, the Dominicans managed to be influential there, they were one religious order among others. And in Valencia, in spite of the early introduction of the Summa - in the 1540 - the theological writing produced there in the first half of the 16th century bears no relationship to Salamanca. ${ }^{8}$ In the universities not controlled by Dominicans, there could be some resistance either against the use of the Summa as the textbook for scholastic theology, since its author was a Dominican, or against the ideas advanced by Dominicans from Salamanca.

lectures, Bartolomé more than once referred to Vitoria’s oral teaching, see Llamas Martínez, Bartolomé de Torres: teólogo y obispo de Canarias, 76 n. 37-38.

6 See Gómez Hellín, "Toledo, lector de filosofía y teología en el Colegio Romano".

7 See Lanza and Toste, "The Sentences in Sixteenth-Century", 418-435, and the bibliography quoted there. We deal with this at greater length in Lanza and Toste, "The Commentary Tradition on the Summa Theologiae", 15-20, 26-30.

8 See Lanza and Toste, "The Sentences in Sixteenth-Century", 472-474 and the bibliography quoted there in note 62 . 
This means that we should not assume that the ideas from Salamanca were necessarily absorbed and endorsed elsewhere in Iberia. Moreover, from the 1540s onwards, the Jesuits started to establish colleges and universities in the Iberian Peninsula, the first ones being the College of Coimbra in 1542 and the University of Gandía in 1547. Once the Jesuits had entered the scene, the theological landscape began to change steadily: Salamanca had to face competition from other influential centres of learning and, what is more, Jesuit universities started to develop a specific way of teaching which was not totally influenced by Salamanca.

The faculty of theology of Salamanca had three major chairs: prima and vespers, in which scholastic theology was taught, and Bible. In the wake of medieval scholasticism, scholastic theology was given more importance than the interpretation of the Bible within university teaching and hence the prima and vespers chairs were ranked above the Bible chair. ${ }^{9}$ For this reason, this chapter concentrates on the influence of Salamanca with regard to scholastic theology. We are fortunate enough that many of the lectures of the 16th-century Salamancan professors survive in manuscripts, the greater part of these lectures being commentaries on the Summa theologiae. Unfortunately, this was not the case everywhere, and the lectures of professors from many Iberian universities are now lost, which makes it difficult to carry out a study on Salamanca's influence over other universities. There are, however, a few cases of universities in which lectures (i.e. commentaries on the Summa) from the 16th century have come down to us and whose libraries (or what remains of their original collections) conserve manuscripts containing Salamancan lectures. Two notable examples of this are the Portuguese Universities of Coimbra and Évora. Numerous manuscripts containing the 16th-century theological production of these two universities are still extant in Portuguese libraries, and the number of manuscripts conserved is so significant that we can reconstruct a great part of the teaching career of some professors. ${ }^{10}$

The aim of this chapter is therefore to present an initial survey of how Salamanca might have influenced the teaching carried out in these two universities.11 The

9 On the organisation of the faculty of theology in the 16th century, see Barrientos García, "La teología, siglos XVI-XVII".

10 This was done in Stegmüller, Filosofia e teologia. Some of Stegmüller's findings have been corrected in Lanza and Toste, "The Sentences in Sixteenth-Century" and "SixteenthCentury Sentences Commentaries from Coimbra: The Structure and Content of Some Manuscripts".

11 We shall study the relationship between Salamanca and other Iberian universities, such as Valencia and Alcalá, in another article. 
article is divided into four parts: in the first, we provide an account of the vehicles through which Coimbra and Évora were influenced by Salamanca; in the second, we analyse the statutes of Salamanca, Coimbra, and Évora and how they determined the teaching of theology in each of these universities; in the third, we offer an overview of the literary production of Coimbra and Évora, highlighting their similarities and differences from Salamanca; finally, in the fourth part, we illustrate how Salamanca influenced Coimbra and Évora with some concrete examples. This last part will show that we should regard neither Salamanca nor other universities as monolithic blocks, for in any university, professors could disagree among themselves about any particular point (as happened in Salamanca, despite the great homogeneity of doctrine found there). Moreover, the influence of a specific Salamancan author - say, Vitoria or Soto - over a professor from another university might depend more on the books and manuscripts available at that university and to that professor rather than on a careful analysis of the different views on the topic at stake that the professor might have held.

In our study, we focus on the lectures produced up to the end of the 1570s. This is because the publication, between 1578 and 1594, of the commentaries on the Summa theologiae by the Salamancan theologians Bartolomé de Medina $\left(\mathrm{I}^{\mathrm{a}}-\mathrm{II}^{\mathrm{ae}}\right.$ and $\left.\mathrm{III}^{\mathrm{a}}\right)$, Pedro de Aragón $\left(\mathrm{II}^{\mathrm{a}}-\mathrm{II}^{\mathrm{ae}}\right)$, Francisco Zumel $\left(\mathrm{I}^{\mathrm{a}}\right.$ and $\left.\mathrm{I}^{\mathrm{a}}-\mathrm{II}^{\mathrm{ae}}\right)$, and Domingo Báñez $\left(\mathrm{I}^{\mathrm{a}}\right.$ and $\left.\mathrm{II}^{\mathrm{a}}-\mathrm{II}^{\mathrm{ae}}\right)$, represents a distinctive break: from that moment on, commentators on the Summa started using and quoting almost only printed texts. ${ }^{12}$ At the same time, other centres outside the Iberian Peninsula rose to prominence and authors elsewhere became more influential than the Salamancans. Suffice it to mention such names as Bellarmine, Gabriel Vázquez, Gregory of Valencia, and Francisco Suárez operating in places such as Leuven, the Roman College, Alcalá, and Ingolstadt. By the late 16th century, the most relevant commentators were no longer teaching at Salamanca; actually, works related to Évora and Coimbra, such as the ones by Molina and Suárez, were far more influential then than works produced by Salamancan professors.

12 Manuscripts continued to circulate and on occasion unpublished texts were still quoted, but this came to a halt by the late 1610 . For a reflection on the circulation of manuscripts after the printing of these Salamancan commentaries, see Schmutz, La querelle des possibles, 567-581, and Lanza and Toste, "Sixteenth-Century Sentences Commentaries", 222-223. For the editorial enterprise undertaken in Salamanca by different religious orders - Dominicans, Mercedarians, and Augustinians - and what it represents in the commentary tradition on the Summa theologiae, see Lanza and Toste, "The Commentary Tradition on the Summa Theologiae", 18-19. 
After several relocations since its foundation in 1290 - from Lisbon to Coimbra and vice versa - the then only Portuguese university was established for good in Coimbra in 1537. In that year the university underwent a great reorganisation almost no professor remained in his position after the relocation from Lisbon to Coimbra and numerous new professors were hired - and in this sense, 1537 stands for a new beginning of the university. Two decades later, another university was founded in Portugal, this time in Évora, where academic teaching started in 1559.

By the 153 os, the Portuguese kingdom was a colonial empire with a growing need for an administrative elite and which, at the same time, lacked cultural prestige at an international level. It was therefore natural to call renowned scholars from abroad in 1537 and in the following years. The most remarkable example of this was the appointment in 1548 of humanists such as George Buchanan and Nicolas de Grouchy, among others, to the College of Arts of Coimbra, which had been instituted by King John III according to the model of the Collège Royal in Paris. ${ }^{13}$ Following the new beginning of the university in 1537 , the appointment of foreigners extended to all the faculties, ${ }^{14}$ but in the cases of canon law, medicine, and theology, the professors who came from abroad were exclusively Spaniards. The presence of Spaniards in the early decades after the establishment of the university in Coimbra was indeed substantial and, more importantly, some of those Spaniards had close ties to Salamanca. The most notable cases are perhaps the first two holders of the prima chair of canon law: the first was the famous Martín de Azpilcueta (15381555), formerly professor at Salamanca, and the second was Juan de Morgovejo (1555-1565, after having held the vespers chair from 1543-1555), who had graduated from Salamanca and had earned his doctorate at Coimbra in $1544 \cdot{ }^{15}$ Moreover, the first holder of the chair of terça (on the Decretum) was Luis de Alarcón, who had also studied at Salamanca. ${ }^{16}$

13 This manner of activity in the college of arts was short lived and in 1555 the faculty of arts started to be run by the Jesuits.

14 The exception was the faculty of civil law, which appointed only Portuguese professors. But in the first decades, even some of the professors of civil law had received their education at foreign universities.

15 On this author, see Guitarte Izquierdo, Un canonista español en Coimbra: el doctor Juan de Mogrovejo (1509?-1566) and García Sánchez, "Relaciones académicas entre Coimbra y Salamanca: un legista, Arias Piñel, y un canonista, Juan Perucho Morgovejo", from page 169 onwards.

16 See Beltrán de Heredia, Cartularium de la Universidad de Salamanca (1218-16oo), vol. 4, 26 (nr. 1293). 
The presence of Spaniards in the faculty of theology was decisive as well, but in this case their origins varied. It is remarkable that when the university relocated to Coimbra in 1537, the men who were appointed to the three existing theological chairs - prima, vespers, and terça (i.e. Bible) - were Spaniards (although none of them had any relationship to Salamanca): Alfonso de Prado, a graduate from Alcalá, was appointed to the prima chair (1537-1557); Francisco de Monzón, another graduate from Alcalá, occupied the vespers chair (1537-1541); and the Dominican Juan de Pedraza, who had studied in the convent of San Pablo in Seville, was selected to the chair of terça (1537-1539). As we shall see later in this chapter, the output of Monzón and Pedraza owed nothing to Salamanca.

It was, above all, Martín de Ledesma, a Dominican from the convent of Salamanca and a pupil of Vitoria and Soto, who paved the way for the reception of the theological ideas of Salamanca in Coimbra. Ledesma first substituted for Pedraza in the chair of terça (1540-1541), but his impact in Coimbra was due to his long tenure. He became the second holder of the vespers chair (1541-1557) and later also the second holder of the prima chair (1557-1574). Because of his long career in Coimbra, his influence and reputation were certainly considerable. ${ }^{17}$ Ledesma was finally replaced in the prima chair by the Portuguese Dominican António de São Domingos (1574-1596), who in turn was replaced by another Spaniard who had studied and taught at Salamanca, the famous Jesuit Francisco Suárez (1597-1616). This means that the prima chair was occupied for more than 6o years by men - two Dominicans and one Jesuit - who favoured the introduction of ideas from Salamanca. This continued for a long time, for, after Suárez, the prima chair was held exclusively by Dominicans until 1648 .

In the vespers chair, the situation was different: after Ledesma, only Portuguese professors held this chair; but between 1557 and 1565 the holders were Dominicans, and being Dominicans they were certainly more prone to draw on Salamancan authors. ${ }^{18}$ There were, however, other Spaniards in the

17 Evidence of this is found in one anonymous commentary, possibly authored by Inácio Dias, a professor of the minor chair of Durand and later of the chair of Scotus. Discussing the question of self-love in Durand's Sentences commentary, Book III, dist. 29, q. 2, the author calls Ledesma "our common preceptor"; see Arquivo Distrital, Braga (ADB), 268, fol. 2or: "Istam sententiam Caietani tenent omnes Salmanticenses et ita tenet doctissimus communis praeceptor noster Laedesmius 2azae q. 26". On this commentary, see Lanza and Toste, "The Sentences in Sixteenth-Century", 481 and "Sixteenth-Century Sentences Commentaries", 251-254. See the beginning of the fourth section of this article where we provide evidence that Ledesma's printed work was known and quoted. 
faculty of theology: Pablo de Palacio y Salazar, who had studied philosophy in Salamanca and had probably earned his doctorate in Évora, became the second holder of the chair of Noa (156o-1563) and the eighth holder of the chair of terça in Coimbra (1563-1566);19 and the Minorite Francisco de Cáceres, who had studied in Alcalá, became the fifth holder of the chair of Durand (1566-1571). ${ }^{20}$

By the end of the 16th century, all the other professors of theology except Suárez were Portuguese, which attests to the regional character that Coimbra eventually assumed. Nevertheless, for our purposes, it is clear that the first 30 years of Coimbra were marked by a strong presence of Spaniards. At the same time, however, we should not overlook the fact that some of the earliest holders of the chairs dedicated to explain the Bible had gained their education in Paris and, in one case, Leuven. ${ }^{21}$ It is thus possible that while the teaching of scholastic theology was undertaken along Salamancan lines, the interpretation of the Bible owed more to Paris and Leuven.

Évora was a different case. Some of its first professors were indeed Spaniards, but their academic paths had been partially or even totally made in Portugal. Of the first four holders of the prima chair of theology, only the first was Portuguese (Jorge Serrão, 1559-1567), the following three were Spaniards. The second holder was Hernán Pérez (vespers chair from 1559-1567 and prima

e Évora no século XVI, 9-35. Rodrigues, A Cátedra de Sagrada Escritura na Universidade de Coimbra. Primeiro Século (1537-1640), 542-549, provides a list of the holders of the two chairs dedicated to the explanation of the Bible (terça and Noa) correcting some of Stegmüller's information.

19 Stegmüller, Filosofia e teologia, 22 (nr. 21). On this author, see Rodrigues, A Cátedra de Sagrada Escritura, 131-156 and Reinhardt, Bibelkommentare spanischer Autoren (15001700), 161-164, and the bibliography quoted there.

20 We could also mention the Portuguese Hieronymite Heitor Pinto, holder of the chair of Noa between 1576 and 1580. Although he had earned his doctorate in Sigüenza (1568), this university served simply as a place to earn the doctorate. In fact, Dominicans from Salamanca, such as Juan Gallo and Domingo Báñez, studied in Salamanca and went to Sigüenza for a few days just to earn their doctorate faster. Heitor Pinto studied in Coimbra and taught in the Hieronymite college of Salamanca in 1568. His teaching there met with great success and Heitor Pinto tried to secure for himself a chair of Sacred Scripture at the University of Salamanca, but he faced the opposition of Luis de León. See Barrientos García, Fray Luis de León y la Universidad de Salamanca, 354-387.

21 António da Fonseca, the fourth holder of the chair of terça (1543-1544), Paio Rodrigues de Vilarinho, the fifth holder of terça $\left(1545^{-1550}\right)$, Álvaro da Fonseca, the sixth holder of the same chair (1551-1560), and Marcos Romeiro, the first holder of the chair of Noa (15451558), all studied in Paris. The ninth holder of terça was Luís de Sotomaior (1567-1589), who studied in Leuven, earned his bachelor's degree in Rome and his master's degree in Avignon. See Rodrigues, A Cátedra de Sagrada Escritura, 74-75, 89-9o, 105-106, 115-116, 16o-162. 
chair from 1567-1572), the third was Luis de Molina (vespers chair from 1568 1572 and prima chair from 1572-1583), and the fourth was Pero-Luis Beuther (1584-1594), known as Pedro Luis. ${ }^{22}$ While Pérez had already graduated when he started teaching in Évora, Molina and Beuther were educated mainly in Portugal: they graduated and earned their doctorates there. Molina had, however, undertaken some study of law in Salamanca and of philosophy in Alcalá, and Beuther had studied at the arts faculty of Valencia. ${ }^{23}$

Two other Spaniards in Évora are worth mentioning here: Ignacio Tolosa, who taught in the prima chair of cases of conscience, ${ }^{24}$ and was also the first man to ever earn a theological doctorate in Évora (1560), ${ }^{25}$ and Pedro Pablo Ferrer. Ferrer, the first holder of the chair of Scripture (1559-1577), represents a different case from the other Spaniards in Évora. A New Christian from Málaga, he had been a professor at the arts faculty of Baeza until 1559, when he joined the Society of Jesus in Alcalá. ${ }^{26}$

Like in Coimbra, in Évora the chairs of theology were all occupied by Portuguese professors by the end of the 16th century. This is noteworthy because Portugal and Spain were a single country from 1580 until 1640. But if we compare the ties between Évora, Coimbra, and Salamanca in the decades in which Spanish scholars held chairs in Coimbra and Évora, it seems that Coimbra had more contact with Salamanca than Évora. ${ }^{27}$ In and of itself, however, the presence of Spanish professors in the two Portuguese universities does not tell the whole story about the transmission of Salamancan ideas. Ideas are transmitted through teaching, but also - and even more so - through the reading of texts. The question is therefore whether Portuguese universities had access to Salamancan texts. Among the late scholastic manuscripts conserved in Portuguese libraries, there are some containing texts that originated

22 For a list of the holders of the chairs of the faculty of theology of Évora, see Stegmüller, Filosofia e teologia, 37-62.

23 On Molina's life, see Stegmüller, Geschichte des Molinismus 1, and Rabeneck, "De vita et scriptis Ludovici Molina". On Beuther, see Reinhardt, "Dokumentation zu Pedro Luis SJ (1538-1602)"; Reinhardt, Pedro Luis SJ (1538-1602) und sein Verständnis der Kontingenz, Praescienz und Praedestination; and Batllori, "El teólogo Pedro-Luis Beuther. Sus primeros años: $1538-155^{8}$.

24 On cases of conscience in Évora, a faculty of its own that was distinct from that of theology, see later in this chapter.

25 Stegmüller, Filosofia e teologia, 63 (nr. 97).

26 See Stegmüller, Filosofia e teologia, 77-78 (nr. 130). On this author, see Soto Artuñedo, $L a$ fundación del colegio de San Sebastián, 94-97 and the bibliography quoted there.

27 For an overview that mentions other scholars, Portuguese and Spanish alike, who were active in Coimbra and Salamanca, see Rodrigues, "Relaciones académicas entre Coimbra y Salamanca: algunos casos destacados". 
in Salamanca. By studying the manuscripts related to Coimbra, which are held at the University Library of Coimbra, and the manuscripts related to Évora, held at the Public Library of Évora and the National Library of Lisbon, we can get an idea of the impact of Salamancan texts in these two universities during the 16 th century.

In Coimbra there are at least 14 manuscripts related to Salamanca. ${ }^{28}$ They are all commentaries on the Summa, the Sentences, and books of the Bible, and all of them came from academic lectures given by Salamancan professors. ${ }^{29}$ These are the following manuscripts: $1834\left(=\mathrm{T}_{1}\right) ;{ }^{30} 1835(=\mathrm{T} 2) ;{ }^{31} 1836\left(=\mathrm{T}_{3}\right) ;{ }^{32} 1841(=\mathrm{T} 8) ; 33$

28 According to Stegmüller, Filosofia e teologia, 242 and 246, two manuscripts, namely 1844 (= T11) and $1858(=\mathrm{T} 27)$, contain works that originated in Salamanca. However, the two manuscripts contain António de São Domingos's lectures on the $\mathrm{I}^{\mathrm{a}}-\mathrm{II}^{\mathrm{ae}}$, qq. $71-114$ and on the $\mathrm{I}^{\mathrm{a}}-\mathrm{II}^{\mathrm{ae}}, \mathrm{q} .4$, art. $6-\mathrm{q} .21$ and qq. 55-88, respectively.

29 In 16th-century Salamanca, the commentaries on the Summa and the Sentences were always related to the classroom (one exception may be the commentary on the Sentences by Miguel de Palacio, published long after he quit his academic teaching). There is no evidence of a commentary produced outside the university walls or outside the religious convents of Salamanca, at least until the 158 os.

30 This manuscript contains three different works: 1 ) lectures on Book I of the Sentences given in 1569-1570 by Luis de León (fols. 1r-82v) and by his substitute Agustín de Mendiola (fols. 89r-113v) (the folios of each author were mistakenly indicated in Lanza and Toste, "The Sentences in Sixteenth-Century", 464 n. 161; this commentary was published in Fray Luis de León, Dios y su imagen en el hombre, ed. Orrego. Orrego described this manuscript at 24-29); 2) Bartolomé de Medina's lectures on the $\mathrm{II}^{\mathrm{a}}-\mathrm{II}^{\text {ae }}$, qq. $77-78$, art. 4 (fols.

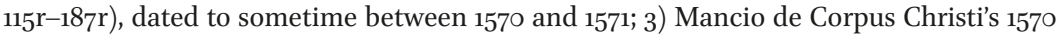
lectures on the $\mathrm{I}^{\mathrm{a}}$, qq. $1-10$, art. 5 (fols. $349^{\mathrm{r}}-43^{2 \mathrm{v}}, 473^{\mathrm{r}}-486 \mathrm{v}$ ).

31 It contains 1) Guevara's lectures on the $\mathrm{II}^{\mathrm{a}}-\mathrm{II}^{\mathrm{ae}}$, qq. $1-8,17-25,32-33,39-41,43$, given in 1569-1572 (fols. 1r-453v) - they were published in Juan de Guevara, O.s.A., La fe, la esperanza y la caridad, ed. Bermejo Jericó; 2) Juan Gallo's lectures on the $\mathrm{II}^{\mathrm{a}}-\mathrm{II}^{\mathrm{ae}}$, q. 62, art. 1-5 (fols. 456r-489r); 3) Bartolomé de Medina's lectures on the $\mathrm{II}^{\mathrm{a}}{ }^{\mathrm{II}}{ }^{\mathrm{ae}}$, q. 62, art. 5-q. 66, art.

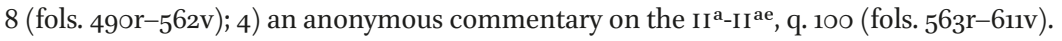

32 It contains 1) Juan Alonso Curiel's lectures on the $\mathrm{II}^{\mathrm{a}}-\mathrm{II}^{\mathrm{ae}}$, qq. ${ }^{-4}$, art. 6, given in ${ }^{1604-}$ 1605 (fols. $1 \mathrm{r}-254 \mathrm{~V}$ ), and on q. 17 with no indication of date, but almost certainly in 1605 (fols. 256r-289r); 2) a commentary by Luis Bernardo on the Gospel of John, produced in 1604 (fols. 3oor-362r); 3) a commentary by the same author on the first chapter of the Epistle to the Hebrews produced in $1604-1605$ (fols. $363^{\mathrm{r}}-408 \mathrm{v}$ ); 4) a commentary on the first chapter of Job by Agustín Antolínez stemming from his lectures in 1605-16o6 (fols. $409 \mathrm{r}-445 \mathrm{v}$ ). This codex contains Salamancan lectures given between 1604 and 16o6, thus indicating that it was likely prepared with this aim in mind.

33 This manuscript contains 1 ) an anonymous commentary on the $\mathrm{II}^{\mathrm{a}}-\mathrm{II}^{\mathrm{ae}}, \mathrm{q} .83$, art. 13-q. 99 (fols. $1 \mathrm{r}-8 \mathrm{OV}) ; 2$ ) a commentary on the $\mathrm{II}^{\mathrm{a}}-\mathrm{II}^{\mathrm{ae}}$, q. 100, possibly by Luis García del Castillo (fols. 81r-10ov); 3) a commentary by Luis García del Castillo on qq. 61-62, art. 6, which came from his lectures in 1576-1577 (fols. 101r-186v); 4) Domingo de Báñez's lectures on the $\mathrm{II}^{\mathrm{a}}-\mathrm{II}^{\mathrm{ae}}$, qq. $64-77$, given in $1577-1578$ (fols. $187 \mathrm{r}-292 \mathrm{~V}$ ), which is identical to his printed 
1843 (= T10); ;4 1845 (= T12); ${ }^{35} 1846$ (= T13); ${ }^{36} 1847$ (= T14); ${ }^{37} 1848$ (= T15); ;8 1849 $(=\mathrm{T} 16) ;{ }^{39} 185^{2}(=\mathrm{T} 19) ;{ }^{40} 1853(=\mathrm{T} 20) ;{ }^{41} 1860(=\mathrm{T} 29) ;{ }^{42}$ and $1875(=\mathrm{T} 45) \cdot{ }^{43}$ The analysis of this set of manuscripts can tell us much about Coimbra.

The most interesting trait of this group of manuscripts is that there are no texts by Vitoria, Soto, or Melchor Cano, that is, the so-called first generation of Salamanca. The authors represented in this group are the Dominicans Pedro de Sotomayor, Mancio de Corpus Christi, Bartolomé de Medina, Juan Gallo, and Juan de la Peña, the Benedictine Luis García del Castillo, the Cistercian Luis Bernardo, the Discalced Carmelite Pedro Cornejo, the secular priests Diego

commentary; 5) an anonymous commentary on the $\mathrm{II}^{\mathrm{a}}-\mathrm{II}{ }^{\mathrm{ae}}$, q. 78 (fols. $293^{\mathrm{r}}-33 \mathrm{Ov}$ ); 6) Pedro de Aragón's lectures on Supplementum, qq. 21-24, art. 3, given in 1576-1577 (fols. 331r-359r). Our description of this codex does not totally coincide with that supplied in Beltrán de Heredia, "Los manuscritos de los teólogos de la Escuela Salmantina", 344. Texts three, four, and six came from lectures given in the minor chairs of Durand and Scotus. It is therefore probable that the manuscript was supposed to contain the teaching carried out in the minor chairs around the years $1576-1578$.

34 It contains lectures by Luis de León on the $\mathrm{I}^{\mathrm{a}}$, qq. 44-62, $\mathrm{I}^{\mathrm{a}}-\mathrm{II}^{\mathrm{ae}}$, qq. 109-113, and on Durand's Sentences commentary on Book III, dist. 40. It also contains Luis de León's De sacra scriptura and his commentary on the $\mathrm{II}^{\mathrm{a}}-\mathrm{II}^{\mathrm{ae}}$, De fide section. See the description of this codex in Fray Luis de León, Tratado sobre la ley, ed. Barrientos García, 46-48.

35 It contains Curiel's lectures on the $\mathrm{I}^{\mathrm{a}}-\mathrm{II}^{\mathrm{ae}}$, qq. $71^{-}-72$, art. 6; qq. $76-80$; q. 109, art. 6. These lectures were given in 1590 and published posthumously in 1618 .

36 It contains a commentary on the $\mathrm{I}^{\mathrm{a}-\mathrm{II}}{ }^{\mathrm{ae}}$ made in $1574-1575$, which is divided as follows: Mancio de Corpus Christi on qq. 1-76 (fols. 1r-322); Bartolomé de Medina on qq. 77-108 (fols. 371-545); Mancio on qq. 109-114; and Juan Gallo on q. 22. On this codex, see Toste, "The Commentaries on Aquinas's Summa", 205-213.

37 This manuscript contains Juan Alonso Curiel's lectures on the Ia, qq. 10-12 given in the academic year 160o-16o1 (fols. 1r-97r) and Pedro Cornejo's lectures on ${ }^{\text {a }}$, qq. 27-32 (fols. 98r-206r).

38 It conserves Pedro Sotomayor's lectures on the $\mathrm{II}^{\mathrm{a}}-\mathrm{II}^{\mathrm{ae}}$, qq. 1-3, $25^{-} 33$, given in $155^{6-1557}$.

39 It contains Guevara's lectures on the $\mathrm{III}^{\mathrm{a}}$, q. ${ }^{-1-25}$, given in $1572-1573$. For this manuscript and others that contain Guevara's lectures (see notes 42 and 43 of this article), see Martínez Fernández, Sacra doctrina, 39-42 and 366-367, where, however, the descriptions of the manuscripts are not complete.

40 It contains Juan de la Peña's lectures on the $\mathrm{II}^{\mathrm{a}}-\mathrm{II}^{\mathrm{ae}}$, qq. 1-78 (fols. $9 \mathrm{r}-532 \mathrm{v}$ ), given in the academic years 1559-1562. On this manuscript, see Pereña Vicente, "Un nuevo manuscrito de Juan de la Peña sobre la Secunda Secundae".

41 This manuscript has the lectures by Mancio and his substitutes on the $\mathrm{II}^{\mathrm{a}}-\mathrm{II}^{\mathrm{ae}}, \mathrm{qq} \cdot{ }^{6}-175$ (fol. 693 until the end) and Juan Gallo's commentary on the II ${ }^{\mathrm{a}}-\mathrm{II}^{\mathrm{ae}}$, qq. 183-189; see Lanza and Toste, "The Sentences in Sixteenth-Century", 459 n. 148.

42 It contains Juan de Guevara's lectures on the $\mathrm{I}^{\mathrm{a}}$, qq. 1-64, given in 1565-1566 (fols. 1-426).

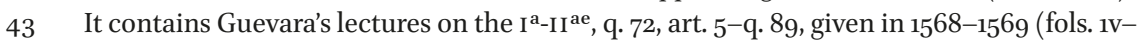
$148 \mathrm{v}$ ) and lectures by Diego Rodríguez Lencina on the $\mathrm{I}^{\mathrm{a}}-\mathrm{II}^{\mathrm{ae}}$, qq. 109-114, given in ${ }^{1568-}$ 1569 (fols. 153v-228v). 
Rodríguez Lencina and Juan Alonso Curiel (wholater became a Benedictine), and the Augustinians Juan de Guevara, Luis de León, Pedro de Aragón, and Agustín Antolínez. Bernardo, Cornejo, Antolínez, and Curiel were active between the last decade of the 16th century and the first decade of the 17th century; the other authors were prominent in Salamanca principally during the 156 os and 1570 os.

In this group there are no manuscripts from the 153 os or 1540s, or even from the first half of the 1550s, that is, the active decades of Vitoria and Soto. The earliest text is Sotomayor's commentary on the $\mathrm{II}^{\mathrm{a}}-\mathrm{II}^{\mathrm{ae}}$, produced in $155^{6-1557}$ and preserved in $1848(=\mathrm{T} 15)$, followed by Peña's lectures on the $\mathrm{II}^{\mathrm{a}}-\mathrm{II}^{\mathrm{ae}}$ given in 1559-1562 and conserved in $185^{2}(=$ T19). The majority of these 14 manuscripts contain texts produced in the 156 os and 1570 os. Moreover, out of 14 manuscripts, only three contain works of the late 16 th and early 17 th centuries: 1836 $\left(=\mathrm{T}_{3}\right), 1845(=\mathrm{T} 12)$, and $1847(=\mathrm{T} 14)$. These three manuscripts have a common trait: they all contain texts by Curiel, who became the holder of the prima chair in Salamanca in 1606 . We shall return to this aspect, but for now it is crucial to underline that these three manuscripts most likely reached Coimbra at a later time and were not part of the initial group. There is indeed a temporal gap between the manuscripts, since there are no texts from the 158 os and only one from the 159os, manuscript 1845 (= T12). How can we explain this?

The editorial enterprise that aimed at publishing commentaries on all four parts of the Summa, which was undertaken by Dominican theologians of Salamanca, was launched in 1578 . The goal was to offer an interpretation of the text with the authoritative brand of the University of Salamanca. ${ }^{44}$ From that moment on, the circulation of manuscripts naturally faded away (although it

44 Upon the publication of the first volume, the Dominicans faced competition from other religious orders that started printing commentaries too. The commentaries authored by Salamancan professors were published in the following order: in 1578, Bartolomé de Medina's commentary on the I $^{\mathrm{a}}-\mathrm{II}^{\mathrm{ae}}$; in 1584 Medina's commentary on the $\mathrm{III}^{\mathrm{a}}$, Domingo Báñez's commentary on the $\mathrm{II}^{\mathrm{a}}-\mathrm{II}^{\mathrm{ae}}$, qq. ${ }^{1-46}$, and Pedro de Aragón's commentary on the same part of the $\mathrm{II}^{\mathrm{a}}-\mathrm{II}^{\mathrm{ae}}$; in ${ }_{15}^{8} 5$, Báñez's commentary on the $\mathrm{I}^{\mathrm{a}}$, qq. ${ }^{1-64}$, as well as the first volume of Francisco Zumel's commentary on the ${ }^{a}$; two years later, in 1587 , Zumel published the second volume - together they covered the entire $\mathrm{I}^{\mathrm{a}}$; then in $159 \mathrm{O}$, Pedro de Aragón's commentary on the $\mathrm{II}^{\mathrm{a}-\mathrm{II}}{ }^{\mathrm{ae}}$, qq. 57-100; finally, in 1594, Báñez's commentary on $\mathrm{II}^{\mathrm{a}}-\mathrm{II}{ }^{\text {ae }}$, qq. $57-88$, and Zumel's commentary on the $\mathrm{I}^{\mathrm{a}}-\mathrm{II}^{\mathrm{ae}}$, qq. $71^{-89}$. This attempt to cover the whole Summa in a few years with printed commentaries authored by Dominicans from Salamanca (Medina and, after his death, Báñez) against the competition, represented by the printing of commentaries by an Augustinian (Aragón) and later by a Mercedarian (Zumel), is apparent. This was obviously an attempt of selfaffirmation undertaken by Salamanca at a time when the Jesuits were already commenting on the Summa in their colleges and were starting to compete with Salamanca and the Dominicans. On this editorial enterprise, see Pena González, "La Universidad de 
did not completely stop, as the existence of later manuscripts attests). But while this explains the scarcity of manuscripts from the 1580 s and 159 os in this group, it does not tell us why Coimbra possesses manuscripts only from the 156os and 1570s, and not from Vitoria's time. A tentative explanation can be offered: it is possible that the Salamancan theologians became famous and authorities of their own beyond the borders of Spain only by the end of the 1550s, that is, after their participation in the Council of Trent and, principally, after the printed publication of Vitoria's Relectiones (1557); Melchor Cano's Relectiones (1550) and De locis theologicis (1563); and Soto's numerous works, such as De natura et gratia (1547), his commentaries on the Epistle to the Romans (1550) and on Book IV of the Sentences (1557), and, most importantly, his De iustitia et iure (1553, second edition 1556). The wider circulation that these works enjoyed might have led professors of Coimbra to search for other works made more recently in Salamanca. But, more importantly, by the end of the $155 \mathrm{os}$, a Dominican was appointed to the prima chair of Coimbra, namely Martín de Ledesma, who held it between 1557 and 1574. He was followed by another Dominican, António de São Domingos (1574-1596). This means that the prima chair of Coimbra was held by two Dominicans for almost four decades. Being Dominicans and holding the most prestigious chair of the faculty, it was natural that they tried to access (and then used and spread) works (and ideas) produced in the leading Iberian university of the time, Salamanca, whose faculty of theology was absolutely dominated by Dominicans and Thomism.

By the same token, we may conjecture that the reason why five of these manuscripts contain texts written by Augustinians - $1834(=\mathrm{T} 1), 1835(=\mathrm{T} 2), 1849$ (= T16), 186o (= T29), $1875\left(=\mathrm{T}_{45}\right)$ - is that, for a long time, two Augustinians held the vespers chair in Coimbra: Francisco de Cristo (1566-1586) and Egídio da Apresentação (1596-1612). Holding such a prestigious position as the vespers chair, these two men were able to get loans from the university for the publication of some of their lectures, ${ }^{45}$ and could, therefore, also have been involved in the acquisition or reproduction of manuscripts. More specifically, Francisco de Cristo may have been the driving force behind the acquisition of the greater part of these texts, since these texts are commentaries by Juan de Guevara and Luis de León which were made at the same time as he held the vespers chair; and Egídio da Apresentação could be responsible for the acquisition of the

Salamanca y el control de la Teología a través de la Summa (siglos XVI-XVII)", and Lanza and Toste, "The Commentary Tradition on the Summa Theologiae", 18-19.

45 See Stegmüller, Filosofia e teologia, 17-19; Taveira da Fonseca, "A imprensa da Universidade de Coimbra no período de 1537 a 1772", 45-46; and Lanza and Toste, "The Sentences in Sixteenth-Century", 477-479 and 486-489. 
three manuscripts containing texts from the late 16 th and early 17 th centuries. Of course, it seems a bit odd that, in the early 17 th century, a professor would still be searching for manuscripts - at the same time, Suárez in the prima chair was purchasing only printed volumes ${ }^{46}$ - but we should not forget that Egídio did not receive the same salary as Suárez and his interests might have been different from those of Suárez.

At any rate, these are only conjectures. There are, however, signs that the teaching of theology in Coimbra did not meet the highest standards - as is attested by a letter sent in 1573 from the father provincial of the Jesuits, Jorge Serrão, to the Father General Everard Mercurian, in which he stated that Coimbra students complained about the teaching of theology and that they thought that the teaching at the Jesuit college was better. ${ }^{47}$ It is thus possible that when a new professor was appointed to the prima chair, António de São Domingos in 1574, he tried to get new material for his lectures in order to compete with the Jesuits. As we shall see in the last section of this article, António was already using some of these Salamancan manuscripts for his lectures in 1575 .

The group of Salamancan manuscripts extant in Coimbra has other important traits. Only four manuscripts have commentaries on the $\mathrm{I}^{\mathrm{a}}$, against five on the $\mathrm{I}^{\mathrm{a}}-\mathrm{II}^{\mathrm{ae}}$ and seven on the $\mathrm{II}^{\mathrm{a}}-\mathrm{II}^{\mathrm{ae}}$ (the $\mathrm{III}^{\mathrm{a}}$ and the Supplementum are underrepresented). What is more, there seems to be a clear intention to have commentaries on the $\mathrm{I}^{\mathrm{a}}-\mathrm{II}{ }^{\text {ae }}$ and, chiefly, on the $\mathrm{II}^{\mathrm{a}}-\mathrm{II}^{\text {ae }}$ that cover large parts of these sections of the Summa, and not merely commentaries on a few questions, and also that, at the same time, these were authored by the holder of a major chair. We thus have lengthy commentaries on the $\mathrm{II}^{\mathrm{a}}-\mathrm{II}^{\text {ae }}$ by Pedro de Sotomayor, Juan de le Peña, Mancio, and Guevara - all holders of the prima and vespers chairs - and the manuscripts that contain their commentaries contain no other work. Guevara stands as a special case: he is the only author in this set of manuscripts to have a commentary on each of the four parts of the Summa (though his commentary on the $\mathrm{I}^{\mathrm{a}}-\mathrm{II}^{\mathrm{ae}}$ only covered 18 questions).

Such a presence of manuscripts with texts on the $\mathrm{I}^{\mathrm{a}}-\mathrm{II}^{\mathrm{ae}}$ and on the $\mathrm{II}^{\mathrm{a}}-\mathrm{II}^{\mathrm{ae}}$ is not an accident. As we shall see in the next section, these formed precisely the core interests of the teaching carried out by Martín de Ledesma and António de São Domingos. This group of manuscripts clearly reflects the interests of Coimbra and therefore the professors might have been involved, in one way or

46 On the acquisition of books by Suárez while in Coimbra, see Brandão, "A livraria do P.e Francisco Suárez", 45-122. The list of books compiled by Brandão is impressive. 
another, in the acquisition of these manuscripts. ${ }^{48}$ Most likely, Coimbra sought to have the most recent Salamancan teaching on scholastic theology. Because, to date, we do not know their origins, we can nevertheless assume that some of the manuscripts were copied in Spain..$^{49}$

It is worth noting that the Salamancan manuscripts conserved in Coimbra contain texts by Mancio de Corpus Christi, Pedro de Sotomayor, Juan de la Peña, and Luis de León. These were men highly regarded in the Iberian Peninsula but probably not known beyond the Pyrenees, since they never published their lectures and their works did not enjoy circulation outside the Peninsula. ${ }^{50}$ Supposing that the Coimbra professors made use of these manuscripts, then the influence of Salamanca over Coimbra might have been unique, for in Coimbra that influence was exerted via authors who did not have much influence anywhere else, such as Mancio and Sotomayor. In other places, even beyond Iberia, the ideas of Salamanca were made known thanks only to those authors who had their works published in print, such as Vitoria, Soto, Medina, and Báñez.

This group of Salamancan manuscripts stands alone and is the most important group of manuscript texts from Salamanca conserved outside Salamanca. ${ }^{51}$ As for other Portuguese libraries, the Public Library of Porto holds two

48 The 1591 statutes of the university stipulated the purchase of books every three years, though it is not clear how far this was actually followed, see Maia do Amaral (ed.), Os livros em sua ordem, 34. By the early 17th century the library had fewer than 800 volumes, see Maia do Amaral (ed.), Os livros em sua ordem, 39.

49 For instance, manuscript $185^{2}$ (= T19), which contains Juan de la Peña's lectures, makes mistakes typical of Spanish speakers, for example not distinguishing the phonetic values of $/ \mathrm{b} /$ and $/ \mathrm{v} /$.

50 Naturally, given the network of Dominican studia, some texts could reach other countries, but this was very rare. Two such exceptions are the manuscript with Sotomayor's commentary on $\mathrm{I}^{\mathrm{a}}$ in Bibliothèque des Quatre Piliers, Bourges, ms. 111, and Österreichische Nationalbibliothek, Wien, 11656 , which contains two relectiones of Vitoria copied in Rome in $1566-1567$.

$5^{1}$ Of course, there is the corpus of nearly 40 manuscripts in the Vatican Library, but that corpus came from the collection of Ascanio Colonna, who studied in Salamanca and Alcalá. This corpus later passed to the Duke of Altemps and then to the Vatican Library, see Ehrle, "Los manuscritos vaticanos de los teólogos salmantinos del siglo XVI: de Vitoria a Báñez",

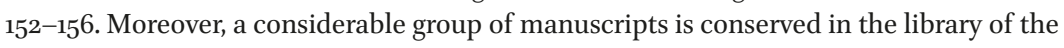
Real Colegio Seminario de Corpus Christi in Valencia, but those manuscripts ended up there because Juan de Ribera (1532-1611), who had studied canon law and theology in Salamanca (1544-1558), became archbishop of Valencia and founded a seminary there and so his manuscripts came to be part of its library. See Rodríguez, "Los estudios del beato Juan de Ribera en la Universidad de Salamanca", and Belda Plans, "San Juan de Ribera y la Escuela de Salamanca". 
manuscripts with texts by Luis García del Castillo, Luis de León, and Bartolomé de Medina, but the manuscripts came from the Oratorians' college in Porto. ${ }^{52}$ The Public Library of Évora holds three manuscripts: one miscellaneous codex with works by Diego de Sahagún, Azpilcueta, and Antolínez among others;53 one manuscript with a commentary on the III ${ }^{\mathrm{a}}$ and Supplementum by Mancio de Corpus Christi (produced in 1568-1570); ${ }^{54}$ and one containing a commentary on the I ${ }^{\mathrm{a}}$ by Soto (1535) and a commentary on the III ${ }^{\mathrm{a}}$, qq. ${ }^{1-}-59$, by Vitoria (1537), which bears the indication, however, that it came from Coimbra (but not the university). ${ }^{55}$

The National Library in Lisbon has 11 manuscripts containing Salamancan texts. These manuscripts came from different places (Évora, Coimbra, and other colleges) and, in some cases, from later private purchases. The manuscripts are the following: COD. $2566 ; 5^{56}$ COD. $2567 ;^{57}$ COD. $2645^{; 8}$ COD.

52 See Aldama, "Manuscritos teólogicos postridentinos de la Biblioteca Municipal de Porto", $23^{-24}$, where the manuscripts $1202 \mathrm{~B}$ and $1202 \mathrm{D}$ are described. All the texts were produced in 1577 .

53 According to Stegmüller, Filosofia e teologia, 272, this codex (CXXIII-1-11) contains ten different texts, one being a commentary on the $\mathrm{II}^{\mathrm{a}}-\mathrm{II}^{\mathrm{ae}}, \mathrm{q}$. 62 . Only an examination of the manuscript could tell us whether some of the texts are commentaries on the Summa or not.

54 Stegmüller, Filosofia e teologia, 272. See also Beltrán de Heredia, "El maestro Mancio de Corpus Christi, O.P.", 384-385, where there is a full description of the codex CxxIII-2-27.

55 This is manuscript CXXIII-1-17, see Stegmüller, Filosofia e teologia, 273 (where the shelf mark is erroneously indicated CXXIII-1-71). See also Beltrán de Heredia, Los manuscritos del maestro Fray Francisco de Vitoria, O.P., 97-99 and Becker, "Tradición manuscrita de las Prelecciones de Domingo de Soto", 162.

56 It contains Juan de la Peña's commentary on the II $^{\mathrm{a}}-\mathrm{II}^{\mathrm{ae}}$, qq. $23^{-} 33$, art. 2, which is part of the text contained in Coimbra, $185^{2}$ (= T19). According to Beltrán de Heredia, it was copied by a Portuguese person. See Beltrán de Heredia, "El maestro Juan de la Peña, O.P.", 504 and Machado Santos, Manuscritos filosóficos do século XVI existentes em Lisboa: catálogo, $210-211$.

57 It contains a commentary on the $\mathrm{II}^{\mathrm{a}}-\mathrm{II}^{\mathrm{ae}}, \mathrm{qq} \cdot 23^{-24}$ (fols. $1 \mathrm{r}-89 \mathrm{v}$ ), by the Augustinian Juan Márquez, holder of the vespers chair in Salamanca between 1607 and 1621. Márquez read these questions in the academic year 1614-15. On this author, see López de Goicoechea Zabala, Juan Márquez, un intelectual de su tiempo.

$5^{8}$ It contains the following works: 1) Curiel's Controversiae in Epistolam ad Hebraeos, produced in 1598 (fols. $1 \mathrm{r}^{-} 5^{2 \mathrm{v}}$ ); 2 ) a commentary on the $\mathrm{I}^{\mathrm{a}}$, q. 12 (fols. $54 \mathrm{r}-142 \mathrm{v}$ ), the first folio of the text and the marginalia of several folios (6or, 72r, 84r, 96r, 108r, and 12or) are attributed to Antolínez, while the colophon in fol. 142v bears indications that it came from the lectures given by Francisco Cornejo in 1599 - in fact, the text actually contains the lectures given by Antolínez in the chair of Durand in 1598-1599 when he was replaced by Cornejo, who started, at the latest, in March 1599 (cf. Barrientos García, La Facultad de Teología de la Universidad de Salamanca, 753-754); 3) Juan Márquez's lectures on the III ${ }^{\text {a }}$, 
$2800 ;{ }^{59}$ COD. $2832 ;{ }^{60}$ COD. $2903 ;{ }^{61}$ COD. $3281 ;{ }^{62}$ COD. $3849 ;{ }^{63} \operatorname{CoD} .3851 ;{ }^{64}$ and COD. 495 1. $^{65}$

What stands out from this group of manuscripts is that it consists of texts chiefly from the 156 os and the 159 os, with Juan de la Peña being the most represented author. To this group, we can add COD. 3023, though this manuscript is probably more related to Coimbra, ${ }^{66}$ and manuscript $44-\mathrm{XII}-20$ from the

qq. 1-14, art. 1, given in 1597-1598 when he replaced Guevara in the vespers chair (fols. $1 \mathrm{r}-283 \mathrm{v}$; the numeration starts anew with this text).

59 This manuscript has 1) lectures given by Peña in 1562 on the III ${ }^{\mathrm{a}}$, qq. $1-29,31,33^{-36}, 41$, 46-47, 52-53, 57, 59 (fols. 1r-162v); 2) Lope Barrio's lectures on the Sentences, Book III, dist. 1, qq. 1-3 (fols. 163r-188v), given in the chair of Scotus in $1560-1561 ; 3$ ) an anonymous commentary on the III ${ }^{\text {a }}$, qq. 6o-64, art. 8 (fols. $189 \mathrm{r}-218 \mathrm{v}$ ). The codex was bought by Francisco Alvarez Pimentel in a later period, see Beltrán de Heredia, "El maestro Juan de la Peña", 506; Machado Santos, Manuscritos filosóficos, 209-210; and Lanza and Toste, "The Sentences in Sixteenth-Century", 466.

60 It contains lectures on $\mathrm{II}^{\mathrm{a}}-\mathrm{II}^{\mathrm{ae}}$, qq. 40, 43-44, art. 6, 57-64 (fols. 2r-97v), and qq. 67-71, 7778 , art. 1 (fols. $98 \mathrm{r}-129 \mathrm{r}$ ). The lectures on qq. $67-78$ are attributed to Juan de la Peña and came from lectures given in the first half of the academic year 1561-1562. See Beltrán de Heredia, "El maestro Juan de la Peña", 5o6, and Machado Santos, Manuscritos filosóficos, 208-209.

61 It contains a short work ( 87 fols.) produced in Salamanca in 1615 by Francisco Cornejo, holder of the chair of moral philosophy (1607-1621). Its title is Tractatus de motivo voluntatis humanae ac de auxiliis divinae gratiae.

62 It preserves a commentary by Martín de Peralta on the entire q. 88 of the $\mathrm{II}^{\mathrm{a}}-\mathrm{II}^{\mathrm{ae}}$ (fols. ir- $35 \mathrm{v}$ ) and an anonymous commentary on the $\mathrm{II}^{\mathrm{a}}-\mathrm{II}^{\mathrm{ae}}, \mathrm{q} .185$, art. $6-7$ and a fragment of article 5 (fols. $36 \mathrm{r}-40 \mathrm{ov}$ ). On fol. 1 r, the manuscript bears the title Addnotationes [sic] super materiam de uoto a doctissimo Doctore Peralta cathedram D. Tho. regente anno salutis 1561, die mensis Julhij 10. This, however, raises a problem, since at that time in the academic year 1560-1561, Peralta lectured on the III ${ }^{\text {a }}$, see Barrientos García, La Facultad de Teología de la Universidad de Salamanca a través de los Libros de Visitas de Cátedras (1560-1641), 447. Further research is needed, but it is not impossible that Peralta switched to $\mathrm{II}^{\mathrm{a}}-\mathrm{II}^{\mathrm{ae}}, \mathrm{q} .88$ in July 1561 and later returned to the $\mathrm{III}^{\mathrm{a}}$ ( since we know that he was reading the $\mathrm{III}^{\mathrm{a}}$, q. 80 on 18 June and the III $^{\mathrm{a}}$, q. 83 on 2 September).

63 The manuscript came from the Jesuit College in Portalegre and contains an anonymous lecture and a lecture by Hernán Pérez on the $\mathrm{I}^{\mathrm{a}}$, plus a commentary by Melchor Cano on the Ia , qq. 65-72, see Stegmüller, Filosofia e teologia, 16o-161. Since it contains lectures by a professor from Évora (Pérez), it was certainly produced in Portugal.

64 It has lectures on the $\mathrm{I}^{\mathrm{a}}$, qq. 1-95, by Pedro de Sotomayor (1561-1563).

65 It has lectures by Báñez on the $\mathrm{I}^{\mathrm{a}}$ (one section bears the date 1596); Antolínez on the $\mathrm{I}^{\mathrm{a}}$, q. 23 (1595-1596); Pedro de Ledesma on some questions of the $\mathrm{I}^{\mathrm{a}}$ (1597); and biblical commentaries by Curiel and the Augustinian Alfonso de Mendoza (who held the chair of Scotus in 1585-1591 and substituted for Juan Guevara in the vespers chair between 1591 and 1596). The codex bears indications that it belonged to "P. Fr. Joao Gorges". A full description of this codex is found in Beltrán de Heredia, "Los manuscritos de los teólogos", 344.

66 This manuscript is not mentioned in Stegmüller, Filosofia e teologia. It contains some of Vitoria's relectiones (fols. ${ }^{1-59}$ ) and Melchor Cano's lectures on the Ia, qq. 1-63, which 
Biblioteca da Ajuda in Lisbon. ${ }^{67}$ Another two codices - COD. 2849 and COD. 3433 - contain works by the Salamancan professor Basilio Ponce de León, though they came from his lectures at Alcalá. ${ }^{68}$ Finally, COD. 2990 contains texts authored by Jesuits from Évora and also a selection of passages from Domingo de Soto and Andrés de Vega on grace, which suggests Jesuit interest in the works of these two Salamancan authors. ${ }^{69}$

It is more difficult to draw conclusions about this group of manuscripts than about the group in Coimbra as it is more heterogeneous: its manuscripts were incorporated into the collection in Lisbon at different times. However, as in the group in Coimbra, there is a strong share of commentaries on the $\mathrm{II}^{\mathrm{a}}-\mathrm{II}^{\mathrm{a}}{ }^{\mathrm{a}}$. The difference is that the $\mathrm{I}^{\mathrm{a}}$ is more represented (four codices) in this group.

What can we conclude from these sets of manuscripts that are conserved in Lisbon, Évora, and Coimbra? Apparently, the relationship between Coimbra and Salamanca was stronger than the relationship between Évora and Salamanca. In his classic work on late scholastic manuscripts in Portuguese libraries, Stegmüller described 53 manuscripts conserved in Coimbra. 14 of the 53 are undoubtedly related to Salamanca. This represents about 25 per cent of the whole group described by Stegmüller. In comparison, the number of manuscripts related to Salamanca extant today in the libraries of Évora and Lisbon is much lower, and their percentage is even lower if we bear in mind that there are many more late scholastic manuscripts in Lisbon and Évora than in Coimbra and, what is more, a considerable number of the manuscripts

were given in 1548 (fols. 62-339). Copied before 1558 , this codex bears the indication "Coimbra" and (by a later hand) "Collegio de Jesús"; see Beltrán de Heredia, Los manuscritos del maestro Fray Francisco de Vitoria, 54-56. Beltrán de Heredia attributed the commentary on the $\mathrm{I}^{\mathrm{a}}$ to Vitoria, and, while such an attribution is still followed in Sarmiento, "Lecturas inéditas de F. de Vitoria: Bases para la edición crítica", 582 and 588 and Delgado, "Manuscritos de las reportationes de los Comentarios a la Prima Pars de Francisco de Vitoria", 276, it is dismissed in Orrego Sánchez, La actualidad del ser en la 'Primera Escuela' de Salamanca, 120-121 and Mantovani, An Deus sit (Summa Theologiae I, q. 2). Los comentarios de la 'primera Escuela' de Salamanca, 155 .

67 This codex is related to COD. 3023 (see previous note). It contains Cano's commentary on the $\mathrm{I}^{\mathrm{a}}$, qq. 1-63 (fols. 1-352), and Vitoria's lectures on the $\mathrm{III}^{\mathrm{a}}$ (fols. $355^{-456)}$ ) and on Book IV of the Sentences (fols. 463-696). Beltrán de Heredia, Los manuscritos del maestro Fray Francisco de Vitoria, $5^{6-57}$, argued that this codex was reproduced by the same copyist as the manuscript COD. 3023, but Mantovani, An Deus sit, 155-156, has shown that this is not the case. The manuscript was bought only in the 18th century.

68 See Stegmüller, Filosofia e teologia, 137 and 153.

69 Stegmüller, Filosofia e teologia, 146. 
now in Lisbon originated in Coimbra. ${ }^{70}$ Subsequent arguments in this chapter will strengthen the view that the ties between Coimbra and Salamanca were stronger than those between Évora and Salamanca.

Numerous studies have analysed the various university statutes of Salamanca in the 16th century, namely the statutes of 1538,1561 , and 1594 , and how they represented a break with the constitutions enacted by Pope Martin V in 1422 . When it comes to the faculty of theology, it has already been shown that the major change was the replacement of Peter Lombard's Sentences with the Summa theologiae as the book that was used to teach theology in the classroom, and how this replacement extended to almost every chair of the faculty of theology. This occurred some decades prior to its official ratification in the statutes of $1561 .{ }^{71}$

The faculty of theology of Salamanca was arranged into major and minor chairs. The major chairs were the prima, vespers, and Bible chairs, while the minor chairs were the chairs of Scotus, St. Thomas, and nominals (later called the chair of Durand). In order to graduate, students had to complete courses in the major chairs alone, for which attendance was mandatory. Because of this, the major chairs held far more relevance than the minor ones. From Vitoria onwards, in the prima and vespers chairs, and often even in the minor chairs, the Summa theologiae was the text that was used and commented on in the classroom. According to the 1561 statutes, the Summa had to be read during nine consecutive academic years in the prima and vespers chairs, as well as in the chair of St. Thomas: one and a half years each for the $\mathrm{I}^{\mathrm{a}}$ and the $\mathrm{I}^{\mathrm{a}}$ $\mathrm{II}^{\mathrm{ae}}$, and three years each for the $\mathrm{II}^{\mathrm{a}}-\mathrm{II}^{\mathrm{ae}}$ and the $\mathrm{III}^{\mathrm{a}}$ with the Supplementum. ${ }^{72}$ In the chairs of Durand and Scotus, the Sentences were to be read within five years, though the last two years were to be dedicated to Book IV. ${ }^{73}$ This means that there was an emphasis on the sacraments and moral issues, the themes of

70 For instance, the greater part of the manuscripts containing Manuel Tavares's lectures in Coimbra is preserved in the National Library of Lisbon. On this author, see later in this chapter.

71 See Barrientos García, "La teología, siglos XVI-XVII", 208-227 and Lanza and Toste, "The Sentences in Sixteenth-Century”, 418-424.

72 Estatutos hechos por la muy insigne Universidad de Salamanca, año 1561, title XII, fol. 23 r.

73 Estatutos hechos por la muy insigne Universidad de Salamanca, año 1561, fol. 23v. In spite of the statute, in practice it was the Summa that was often used in these two chairs. 
Book IV of the Sentences and the $\mathrm{II}^{\mathrm{a}}-\mathrm{II}^{\mathrm{ae}}$ and the $\mathrm{III}^{\mathrm{a}}$. With the 1594 statutes, this was extended to 16 years to lecture the entire Summa: three years for the $\mathrm{I}^{\mathrm{a}}$, three years for the $\mathrm{I}^{\mathrm{a}}-\mathrm{II}^{\mathrm{ae}}$, five years for the $\mathrm{II}^{\mathrm{a}}-\mathrm{II}^{\mathrm{a}}{ }^{\mathrm{a}}$, and finally five years for the $I I I^{a}$ and the Supplementum. ${ }^{74}$ In the chairs of Durand and Scotus, the total time was extended (Book I was to be read in two years; Book II in three years; Book III in another three years; Book IV in four years). ${ }^{75}$ Again, the sacraments and moral topics were given more attention.

It is well known that the Salamancan statutes were explicitly used as a model - and sometimes even reproduced verbatim - for the statutes of numerous Spanish universities, both in Spain and the colonies. ${ }^{76}$ This was not the case with the Portuguese universities. In Coimbra, the Dominicans were influential - between 1557 and 1648 all the holders of the prima chair except Suárez (1597-1616) were Dominicans -, yet they never rose to the prominence they had in Salamanca and thus shared the decision-making and teaching with secular clergy, Augustinians, Benedictines, Carmelites, and, to a lesser extent, Cistercians, Franciscans, and others. ${ }^{77}$ This might explain why the Summa theologiae was adopted rather late there in comparison to Salamanca. It started to be the basis for the lessons in the prima chair only in 1574, at least officially, which was nearly half a century after Vitoria had introduced this procedure in Salamanca.

In the vespers chair, however, the Summa started to be used as early as 1541 by direct order of King John III. ${ }^{78}$ The king's order was made under the influence of the interim rector of the university, the Dominican Bernardo da Cruz, who had professed in the Convent of San Esteban in Salamanca and most likely coincided with Vitoria there. ${ }^{79}$ The decision met with some resistance,

74 Estatutos hechos por la muy insigne Universidad de Salamanca [1595], title XII, 17.

75 Estatutos hechos por la muy insigne Universidad de Salamanca [1595], 18-19.

76 See Lanza and Toste, "The Sentences in Sixteenth-Century", 428-435 and 493-494, and the bibliography there.

77 Note that in the first years after the relocation of the university to Coimbra, that is, between 1537 and 1544, lessons were taught in the Augustinian monastery of Santa Cruz. So, in contrast to Salamanca, where the Dominican Convent of San Esteban had a prominent role in the life of the university, the Dominican convent could not have such a role in Coimbra.

78 Cf. Brandão, Documentos de D. João III, vol. 2, 71-72. There is table with an indication of which text (and part) should be read in each of the four main chairs (prima, vespers, and the two chairs for the Bible) for each academic year between 1546 and 1608 in Taveira da Fonseca, "A teologia na Universidade de Coimbra", 792 and 794-795. See also Rodrigues, "Padres agostinhos do século XVI lentes de teologia da Universidade de Coimbra". It should be noted that the decision over the books that were supposed to be read was not always followed by the professors. On Bernardo, see Silva Dias, A política cultural da época de D. João III, vol. 1, 305-311. 
including no less than the holder of the prima chair, the Spaniard Alfonso de Prado, who had graduated from Alcalá and not from Salamanca: in a letter to the king he argued that the faculty only needed two chairs, one for the Sentences and another for the Bible. ${ }^{80}$

The adoption of the Summa in the vespers chair coincided with the appointment of Vitoria's student, the Dominican Martín de Ledesma, to the chair, which he held between 1541 and 1557. We do not know whether Ledesma was able to lecture on the Summa when he was appointed to the prima chair in 1557, but his commentary on Book IV of the Sentences, published in two volumes in 1555 and 1560, despite nominally being a commentary on the Sentences, followed the order of the Summa. ${ }^{81}$ And the same holds for his unpublished commentary on Book II of the Sentences, which stems from his lectures in the prima chair in $1560 .{ }^{82}$ So officially he was lecturing according to the Sentences in the prima chair, but in reality he most likely followed the Summa, just as he did in the vespers chair. What we know is that when António de São Domingos, another Dominican, was appointed to this chair after Martín de Ledesma in 1574, the Summa started to be used permanently in the prima chair. ${ }^{83}$

Like in Salamanca, the introduction of the Summa in Coimbra was thus strictly connected with the Dominicans. But since they did not completely control the university and had, nevertheless, been able to secure a chair for the Summa since the 1540 , it is quite possible that professors from other religious orders demanded an offset to prevent the supremacy of Thomism in Coimbra to the detriment of other schools of thought. In fact, a chair of Biel was created in 1560 and a chair of Scotus in 1562 - the latter was apparently turned into a major chair subsequently. ${ }^{84}$

The structure of the faculty of theology was also different from that of Salamanca. The faculty had started with only two chairs in the early 16 th century, but in 1537 there were already two chairs for scholastic theology and, in

8o Silva Dias, A política cultural da época de D. João III, vol. 1, 670-672, and Rodrigues, A Cátedra de Sagrada Escritura, 49 n. 2.

81 See Lanza and Toste, "The Sentences in Sixteenth-Century", 475-476. Ledesma was not the only author to publish a commentary on the Sentences which was in fact a commentary on the Summa.

82 Lanza and Toste, "The Sentences in Sixteenth-Century", 476.

83 A chronological table of his lectures, with an indication of the manuscripts in which the lectures of each academic year are preserved, can be found in Xavier Monteiro, Frei António de São Domingos e o seu pensamento teológico: sobre o pecado original, 106-108.

84 In "The Sentences in Sixteenth-Century", 427, we say that the chair of Scotus became a major chair with the 1597 statutes. This is not correct. This chair was turned into a major chair, but it was never mentioned as such in the statutes. 
1545, a further chair was created for the interpretation of the Bible (the chair of Noa). This was ratified in the 1559 statutes, according to which there should be four major chairs: prima (where the Sentences, along with a Sentences commentary of the professor's choice, was the standard reading), vespers (where the Summa was the textbook), terça (for the explanation of the New Testament), and Noa (dedicated to the interpretation of the Old Testament). ${ }^{85}$ The statutes are silent on the minor chairs, but, apart from the chairs of Biel and Scotus, there was also a chair of Durand from the 1540s, and it is known that there was a chair of St. Thomas in 1545, at least. ${ }^{86}$ By contrast, the statutes of 1592 mentioned three minor chairs: Durand, Scripture, and St. Thomas (where, if the professor wished, Biel's commentary on the Sentences could be read instead). ${ }^{87}$

The statutes do not indicate the length of time over which the Summa and the Sentences should be taught, but, according to the proceedings of the meetings of the council's reunions which determined the topics that were to be taught in the following academic year, each book of the Sentences was clearly read in two and sometimes three academic years (for instance, Book I in 15581561; Book IV in 1564-1567). When the Summa was read, the I a took three years $\left(1563^{-1566)}\right.$, the $\mathrm{I}^{\mathrm{a}-\mathrm{II}}{ }^{\text {ae }}$ took two years $\left(1553^{-1555}\right.$ and $\left.1568-1570\right)$, and, on one occasion, the $\mathrm{II}^{\mathrm{a}}-\mathrm{II}^{\text {ae }}$ took four years $\left(1555^{-1559)}\right)$. As in Salamanca, the pace of the lectures became slower with time and by the end of the 16th century, only a few questions of the Summa were covered in one entire academic year. For instance, in 1601-1602, the holder of the chair, Suárez, covered only the De legibus (qq. 90-108), and in the following year, he commented solely on the De gratia (qq. 109-114). Previously, the De fide, which consists of 16 questions, was covered in two years (1594-1596).88

Regarding the topics covered, it is notable that, whenever the holder of the chair was a Dominican, he rather privileged moral and sacramental topics.

85 Estatutos da Universidade de Coimbra (1559), ed. Leite, cap. 29, 90-91. Significantly, the statutes opened the possibility that, if the professor of the prima chair read the Summa, then the professor of the vespers chair read the Sentences, and vice versa. This seems to be a further sign that Martín de Ledesma, appointed to the prima chair in 1557, i.e. two years prior to the approval of the statutes, was already lecturing according to the Summa. It should be noted that in all the successive statutes - 1592, 1597, and $1643-$, the prima chair remained officially the chair for the Sentences.

86 See Silva Dias, A política cultural, vol. 1, 675-676.

87 Estatutos da Universidade de Coimbra. Confirmados por el Rei Dom Phelippe primeiro deste nome, nosso Senhor, em o anno de 1591, Liber III, titulo 5, 73; Statutos da Vniversidade de Coimbra confirmados por el Rey Dom Philippe Primeiro deste nome, nosso senor em o anno de 1597, fols. 145v-146r; Estatutos da Universidade de Coimbra (1653), Liber III, titulo 5, 142.

88 See Taveira da Fonseca, "A teologia na Universidade de Coimbra", 795 and Rodrigues, "Padres agostinhos", 337 . 
In this regard, it is remarkable that, during the 16 years in which Martín de Ledesma held the vespers chair, he only taught topics exclusively related to the $\mathrm{I}^{\mathrm{a}}-\mathrm{II}^{\mathrm{ae}}$, the $\mathrm{II}^{\mathrm{a}}-\mathrm{II}^{\mathrm{ae}}$, and the $\mathrm{III}^{\mathrm{a}}$. Ledesma never dealt with the $\mathrm{I}^{\mathrm{a}}$ in that chair and therefore with more metaphysical topics, such as God's essence, the Trinity, the Creation, and angels. And the same more or less happened when António de São Domingos held the prima chair (1574-1596): he read the $\mathrm{I}^{\mathrm{a}}-\mathrm{II}^{\mathrm{ae}}$ from 1574 to 1578 , the $\mathrm{II}^{\mathrm{a}}{ }_{-\mathrm{II}}{ }^{\text {ae }}$ from 1578 to 1586 , the $\mathrm{I}^{\mathrm{a}}$ from 1586 to 1589 , and the sections on matrimony and the Resurrection from the Supplementum in his final years, $1590-1593$. In the span of 20 years, he explained the $\mathrm{I}^{\mathrm{a}}$ in only three years. ${ }^{89}$ The stress on moral and sacramental topics continued with the arrival of Suárez to the prima chair (1597-1616). He lectured firstly on the De poenitentia (1597-1598), then on the De Deo uno (1598-1599), then on the I ${ }^{\mathrm{a}}-\mathrm{II}^{\text {ae }}$ between 1601 and 1609 (including the De legibus and the De gratia), and finally on the Defide.

Such a stress on moral and sacramental topics is not found in the lessons taught in the chairs of Durand, Scotus, and Biel, which were never held by Dominicans. There is no detailed information about the teaching content of the minor chairs, but, thanks to the surviving manuscripts, it is possible to have a glimpse of it. Of all the holders of the chairs of Durand, Scotus, and Biel whose lectures have survived, only two dealt with topics related to the $\mathrm{II}^{\mathrm{a}}-\mathrm{II}^{\mathrm{ae}}$. These were the Carmelite Manuel Tavares - who, at different times, held the chairs of Durand and Scotus, and left commentaries on $\mathrm{II}^{\mathrm{a}}-\mathrm{II}^{\mathrm{ae}}$, qq. 9-10 (on infidelity), 26-33 (on charity), 62 (on restitution), and 78 (on usury) - and the Cistercian Francisco Carreiro, who lectured on the De fide in 1593 in the chair of Biel and on $\mathrm{II}^{\mathrm{a}}-\mathrm{II}^{\mathrm{ae}}, \mathrm{q} .33$, in 1609 in the chair of Scotus. ${ }^{90}$ All the other holders of minor chairs focused on themes such as the Trinity, angels, original sin, and the Eucharist. ${ }^{91}$ The two exceptions can be explained by the fact that the Carmelites were traditionally somewhat close to Aquinas's doctrine and, in 1593, they adopted the Summa for teaching theology in their convents. ${ }^{92}$ As for the Cistercians, they never selected an author who had to be followed doctrinally and thus would have no reason to oppose teachings based on the Summa.

89 See Xavier Monteiro, Frei António, 106-10 and Taveira da Fonseca, "A teologia na Universidade de Coimbra", 794-795.

90 See Stegmüller, Teologia e filosofia, 30-32. There is also an anonymous commentary, tentatively attributed to Inácio Dias, which covered Durand's commentary on the Sentences, Book III, dist. 26-39, and therefore topics related to charity and the virtues. On this work, see note 17 above.

91 For the list of questions in these texts, see Lanza and Toste, "The Sentences in SixteenthCentury", 498-503 and "Sixteenth-Century Sentences Commentaries", 231-279. See Lanza and Toste, "The Commentary Tradition on the Summa Theologiae", 37. 
How much did Coimbra differ from Salamanca in its teaching content? Scholars have been able to reconstruct what men like Vitoria, Soto, Mancio de Corpus Christi, Juan de la Peña, Juan de Guevara, Luis de León, and Bartolomé Medina actually taught in every academic year they spent in Salamanca with a high degree of certainty. ${ }^{93}$ In all these cases, we do not find a clear preference for teaching topics particularly related to the sacraments and morals: they lectured on all parts of the Summa. ${ }^{94}$ We noted earlier that the 1561 statutes gave some prominence to sacramental and moral issues, stipulating that professors spend more years on the $\mathrm{II}^{\mathrm{a}}-\mathrm{II}^{\mathrm{ae}}$ and the $\mathrm{III}^{\mathrm{a}}$. But should we assume that the Salamancan authors privileged moral themes as the two Dominicans of Coimbra did? Would the Salamancan authors have regarded themselves as moral theologians or simply as theologians who dealt with moral themes too? Most likely, they felt the need or were requested to engage in debates of great social and political impact, and their participation in such debates was also linked to their need to stress their own social role and importance as theologians. But since they were first and foremost university professors, they were educated to address a wide variety of topics, such as the creation of the world, the Trinity, angels, the moral and theological virtues, and the sacraments. While their relectiones were consumed by audiences far beyond the university walls, therefore being seen by the Salamancan masters as an occasion to deal with pressing issues - which explains why the relectiones of Vitoria, Soto, Cano, and Peña addressed moral and sacramental topics - their academic lectures were exclusively aimed at the university, in which milieu morals was but one topic among many. Against this backdrop, the case of the Coimbra Dominicans

93 For Vitoria, there is an overview in Belda Plans, La Escuela de Salamanca, 336-337; for Soto, see Becker, "Tradición manuscrita"; for Mancio, see Beltrán de Heredia, "El maestro Mancio", 381-388; for Juan de la Peña, see Beltrán de Heredia, "El maestro Juan de la Peña", 498-5o1; for Juan de Guevara, see Martínez Fernández, Sacra doctrina, 37-43; for Luis de León, see Barrientos García, Fray Luis de León, 175-179 and 192-206; for Medina, see Barrientos García, "Bartolomé de Medina, O.P. y la Universidad de Salamanca". Barrientos García's recent work, La Facultad de Teología de la Universidad de Salamanca, represents a true landmark in the scholarship by providing a detailed account of the teaching content of all the masters of theology in Salamanca between 156o and 1641. Nonetheless, Barrientos García did not indicate many of the manuscripts in which the lectures are preserved.

94 The exception was Juan de la Peña who taught in the prima chair between 1559 and 1565 . He started with the $\mathrm{II}^{\mathrm{a}}-\mathrm{II}^{\mathrm{ae}}$ in $1559^{-1560}$ and continued with $\mathrm{III}^{\mathrm{a}}$. His teaching on the $\mathrm{III}^{\mathrm{a}}$ was interrupted by his death during the academic year $1564-1565$, so we may presume that, if he had not died, he would have lectured on the $\mathrm{I}^{\mathrm{a}}$ the next year, since he read the III $^{\mathrm{a}}$ after the $\mathrm{II}^{\mathrm{a}}-\mathrm{II}^{\text {ae }}$ and would have started the Summa from the $\mathrm{I}^{\mathrm{a}}$ (this was the normal procedure). 
Martín de Ledesma and António de São Domingos has to be understood as an intensification or increase in the interest of topics that were only slightly favoured in Salamanca.

The University of Évora is a different case. It was one of the first universities that was run exclusively by the Jesuits. The Jesuits began teaching there from the beginning, when it was only a college, in 1551 . This was only three years after the foundation of the first ever Jesuit university - Gandía in 1548 - and of the first Jesuit college - Coimbra in $1542-$, and two years before the beginning of teaching activity in the Roman College in 1553. The university owes its origin to Cardinal Henry, archbishop of Évora and brother of King John III. When Henry founded a college in Évora in 1551, he asked the Jesuits to run it and so, when eight years later in 1559 the papal bull Cum a nobis turned the college into a university, its administration and teaching were already in the hands of the Jesuits. ${ }^{95}$

Évora was not the first city in Portugal where Jesuits had started to give lectures. Established in Lisbon and in Coimbra in 1542, the Jesuits were granted the right to lecture at the University of Coimbra as early as 1544. The following year, they also gave lectures at their own Coimbra College and, to the dismay of the university, a few years later, those lectures included theology. A decade later, in 1555, King John III offered the Jesuits the control of the arts faculty of Coimbra and, from that moment on, they alone taught at the arts faculty, which later resulted in the famous Cursus Conimbricensis. ${ }^{96}$ The Jesuits also gave public lectures at their college in Lisbon from 1552. They were thus already present in the two main places of the kingdom - the capital and the town with the country's only university - when they started running Évora. Évora was thus related to these two cities from the beginning, and numerous Jesuits were professors and had been students in all three places - Évora, Coimbra, and Lisbon - or at least in two of them. ${ }^{97}$

Because it was a Jesuit university, Évora pursued a different path from Salamanca and Coimbra. Its aim was not merely to equip the clergy with theological culture, but to train priests and prospective missionaries for the

95 For an overview of the foundation of the University of Évora, see Queirós Veloso, $A$ Universidade de Évora.

96 On the arrival of the Jesuits in Coimbra and how they managed to gain control of the arts faculty, see Casalini, Aristotele a Coimbra, 59-93.

97 For this reason, the study of the teaching of theology in Évora cannot be dissociated from the study of the Jesuit College of Coimbra. This, however, has yet to be undertaken, since so far, the historiography has only concentrated on the Jesuit teaching at the arts faculty of Coimbra. We plan to do so in a future publication. 
Portuguese empire overseas. Some of its professors later went to the Azores, India, Japan, and Brazil - for instance, Cristóvão Gil, Pedro Martins, and Luís de Cerqueira, professors of theology, and Ignacio Tolosa and Nicolau Pimenta, professors of cases of conscience - and the university received students from those places too (albeit in limited numbers). This aspect helps to explain the curriculum studiorum and the output of Évora. As we try to show in the next pages, the importance of this university should not be underestimated:Molina's De iustitia et iure came from the lectures he gave in Évora and has to be seen against the background of the teaching carried out there; the production that resulted from teaching cases of conscience was probably unique in Europe; the university gained prestige in the Society of Jesus, and some of its professors went to teach at the Roman College - Nicolau Godinho, who held the vespers chair of theology in Évora (1597-1604), Francisco da Costa (vespers chair, 1610), and Simão Vieira. Moreover, Gaspar Gonçalves, holder of the third chair of theology in Évora (1567-1579), later became a member of the committee responsible for the redaction of the Ratio studiorum.

The statutes of the University of Évora were promulgated in $1563 .{ }^{98} \mathrm{Just}$ a few years later, however, in 1567 , new statutes were enacted. ${ }^{99}$ Possibly, these statutes were also soon revised, for another manuscript contains another version of the statutes which bears the date $1570 .{ }^{100}$ For the sake of simplicity, we will call this version the 1570 statutes. In any case, these statutes were effective until the first half of the 17th century, when new statutes were made (their precise date is unknown). ${ }^{101}$

98 The first statutes are conserved in two manuscripts and have never been published: Arquivo da Universidade, Coimbra (AUC), U. Évora 2, and AUC, U. Évora 3 (the former is probably a draft of the latter). For the date of these and of the second statutes, see Queirós Veloso, A Universidade de Évora, 44-45.

99 They are contained in the manuscript AUC, U. Évora 4, which bears the date 1567. The statutes remain unpublished.

100 The statutes are found in the manuscript Évora, Biblioteca Pública (в Ре), CXIV-2-31. The first folio bears the indication "Almeirim 1570". As Almeirim is more than 100 kilometres away from Évora, this suggests that the manuscript was copied on that date and at that place, though not necessarily that the statutes were enacted on that date. The historiography has always assumed that this manuscript contains the exact same text as the manuscript quoted in the previous footnote. A comparison of the two texts shows that this is not true (suffice it to see the quotations in the next footnotes) and thus further research is needed. A transcription of this manuscript can be found in Marques Pereira and Vaz, Antologia de textos da Universidade de Évora.

101 These statutes are conserved in the manuscript Biblioteca Nacional, Lisbon (BNL), COD. 8014 and bear the title Estatutos da Universidade de Évora ... revistos por ordem do Reverendo Padre Mutio Vitelleschi, prepósito geral da Companhia de Jesus, which means that they were made between 1615 and 1645 when Vitelleschi was the Superior General 
The first statutes lack detailed information regarding teaching content, but it is evident that, along with theology, arts, and humanities, the university also offered a degree in cases of conscience, which constituted a faculty of its own. ${ }^{102}$ Regarding the faculty of theology, the statutes listed three chairs: prima, vespers, and Sacred Scripture. ${ }^{103}$ The content of each chair was specified in the 1567 statutes: the faculty of theology consisted of two chairs of scholastic theology (prima and vespers chairs), which were expressly dedicated to the teaching of Aquinas, and one chair of Sacred Scripture - not two as in Coimbra. ${ }^{104}$ The 1570 statutes added a third chair of scholastic theology, ${ }^{105}$ which was later confirmed in the 17th-century statutes. ${ }^{106}$ In this respect, Évora followed the Roman College, where a third chair of theology had been established ten years earlier, in 156o. It is noteworthy that, in contrast to Coimbra and Salamanca, there were no minor chairs in Évora, Thomism being thus the only school of thought officially taught.

But the most remarkable difference from Salamanca and Coimbra was that Évora had another faculty and another course of study: cases of conscience. All the statutes but the first stipulated two chairs of cases of conscience. ${ }^{107}$ The two chairs, however, existed as early as $1561 .{ }^{108}$ The study of cases of conscience

of the Society of Jesus, see Queirós Veloso, A Universidade de Évora, 46 n. 5 . They have recently been published in Rosa, História da Universidade teológica de Évora (séculos XVI aXVIII).

102 See AUC, U. Évora 2, fol. 1r (chapter 1); AUC, U. Évora 3, fol. 5 r.

103 See AUC, U. Évora 2, fol. 13r-v (chapter 19); AUC, U. Évora 3, fol. 23v.

104 AUC, U. Évora 4, fol. 31r: "Liuro terceiro que trata do exercicio das letras, actos, e graos. Capitulo $\mathrm{I}^{\circ}$ das licoes que adauer na vniuersidade e que nao haja em outra parte. Auera na Vniuersidade [...] tres licoes de theologia, duas dellas de Santo Thomas e outra da sagrada Escritura [...]". It should be noted that there is no explicit mention of a degree or of academic exams of cases of conscience in this codex or in the manuscripts containing the first statutes. However, in the first chapters of the statutes, cases of conscience was always mentioned as distinct from theology and listed along with arts, humanities, and theology. In this manuscript, see fol. $3 \mathrm{v}$ (Book I, chapter 3).

105 "Livro $3^{\circ}$ que Trata do Exercício das Letras, Autos e Graus. Cap. $1^{\circ}$ Das Lições que há-de haver na Universidade, e que as não haja em outra parte. 1. Haverá na Universidade [...] 4 lições de Teologia, 3 delas de S. Tomás, e outra da sagrada escritura [...]", quoted from the CD-Rом in Marques Pereira and Vaz, Antologia de textos.

106 Rosa, História da Universidade, 199: "Liuro 3. Do Exercicio de Letras, Actos, e Graos. Capitulo 1. Das Liçõis, e faculdades, que ha de auer na Uniuersidade, e que as não aia em outra parte. 1. Auerá na Uniuersidade [...] quatro liçõis de Theologia, tres de Santo Thomas, e outra de sagrada escriptura [...]".

107 AUC, U. Évora 4, fol. 3ır (Book III, chapter 1): "[...] duas licoës de Casos de Consciencia”; Marques Pereira and Vaz, Antologia de textos: "[...] e duas lições de casos de consciência”; Rosa, História da Universidade, 199: "[...] e mais duas de Theologia moral, ou casos de consciencia".

108 See note 113, below. 
was not an invention of Évora. The Roman College started teaching cases of conscience daily in 1556 and it became an independent course of study from theology in ${ }^{1563} .{ }^{109}$ In the following years the cases of conscience course spread to all Jesuit colleges. The pastoral aim of this course is clear and was part of the Jesuit trend towards a more practical university curriculum: it was aimed at those students who were considered less talented but who would nevertheless have pastoral responsibilities. ${ }^{110}$

There were three differences between Évora and the Roman College: firstly, there were two chairs of cases of conscience at Évora and only one at the Roman College; secondly, in Évora, the degree of cases of conscience took three years whereas the Ratio studiorum specified two years; ${ }^{111}$ thirdly, in Évora there was no chair dedicated to religious controversies, unlike in the Roman College, where Bellarmine held such a chair. But Évora is also an interesting case for two other reasons: we know which text was used in the two chairs of cases of conscience and many of the lectures have survived in manuscript form.

The 1567 and 1570 statutes were silent about the texts that had to be used, though the 17th-century statutes tell us that no student of cases of conscience could be admitted to the exam unless he had with him an exemplar either of the Summa Caietani, or Navarrus's Manual, or Francisco de Toledo's Instructio sacerdotum. ${ }^{112}$ However, a document with the records of the classes taught in Évora from 1561 to 1563 sheds some light: in those four years at least, the Summa Caietani was the text used in the two chairs. ${ }^{113}$ This matches what was happening at the same time in other Jesuit colleges, such as Cordoba and Barcelona. ${ }^{114}$ It also disproves Angelozzi's statement that Juan Alfonso de Polanco's Breve directorium ad confessarii ac confitentis munus rite obeundum (1554) was perhaps the most widely-used work in Jesuit classes of cases of conscience. ${ }^{115}$ Theiner noted that, at least in 1551, Martín de Azpilcueta (Navarrus)

109 See Pozo, "La Facoltà di Teologia del Collegio Romano nel XVI secolo", 18 and 26-28, and O'Malley, The First Jesuits, 146.

110 On cases of conscience in Jesuit colleges, see Angelozzi, "L'insegnamento dei casi di coscienza nella pratica educativa della Compagnia di Gesù".

111 See Rosa, História da Universidade, 179-180.

112 See Rosa, História da Universidade, Apêndice documental, 199 (Book IV, chapter 1, nr. 12). Toledo's work was published only in 1599 and came from his lectures at the Roman College, see O'Malley, The First Jesuits, 147.

113 Monumenta Pedagogica Societatis Iesu. Nova editio penitus retractata. III (1557-1572) ** , ed. Lukács, 58.

114 See Theiner, Die Entwicklung der Moraltheologie zur eigenständigen Disziplin, 125. Not all Jesuits regarded Cajetan's Summa peccatorum favourably, see Maryks, Saint Cicero and the Jesuits. The Influence of the Liberal Arts on the Adoption of Moral Probabilism, 73-75.

115 See Angelozzi, "Linsegnamento dei casi di coscienza", 138-139. 
was the author used in the Lisbon College. ${ }^{116}$ However, lectures on Navarrus were certainly short lived, both in Lisbon and in Évora. We know this because of the numerous manuscripts containing lectures of cases of conscience held in Évora, Coimbra, and Lisbon: they are commentaries on the Summa Caietani. In his catalogue of late scholastic Portuguese manuscripts, Stegmüller classified many of these texts as commentaries on the $\mathrm{II}^{\mathrm{a}}{ }^{\mathrm{II}} \mathrm{I}^{\text {ae }}$ of the Summa theologiae, reasoning that their titles corresponded to questions or sections of the Summa. As we will see in the next section, a more detailed analysis invalidates such a view: although Aquinas's Summa was often quoted in these works, it was not taken as the source text for these commentaries. For now, the point is to stress that Azpilcueta's Manual was not the basis for teaching cases of conscience and it is not unsurprising that one holder of the prima chair of cases of conscience at Évora, Francisco de Gouveia (1573-1585), wrote a work entitled Annotationes super Manuale Navarri (sometime between 1575 and 1579). Given its criticism of Azpilcueta, it came to be known as Antinavarrus. ${ }^{117}$

\section{The Output of Coimbra and Évora}

Obviously, the institutional arrangement of the faculties of theology of Salamanca, Coimbra, and Évora influenced the theological output of each of these three universities. The texts of 16th-century professors of Coimbra were essentially commentaries on the Summa, the Sentences, and specific books of the Bible, and in this they did not differ from their Salamancan fellows. Just like the Salamancan commentaries, the vast majority of the texts produced in Coimbra remained unpublished. Only two 16th-century professors were able to have their lectures of scholastic theology printed:118 Martín de Ledesma published a commentary on Book IV of the Sentences (1555-1560), which was influenced by Domingo de Soto's commentary on the same book, and the Augustinian Francisco de Cristo, the holder of the vespers chair for 20 years (1566-1586), published one commentary on Book I (1579) and another on Book III of the Sentences (1586). ${ }^{119}$ Martín de Ledesma's commentary, known

116 Theiner, Die Entwicklung, 125; see Joannes Alphonsus de Polanco, Chronicon Societatis Iesu. Vita Ignatii Loiolae et rerum Societatis Jesu historia, vol. 3, 403, nr. 889 .

117 It is published in Olivares, "Francisco de Gouvea S.I. (1540-1628). Introducción y edición". Gouveia used the Latin text of Azpilcueta.

118 Egídio da Apresentação and Suárez published their disputations (more or less related to the Summa) in the first decade of the 17 th century.

119 Stegmüller, Filosofia e teologia, 17, attributes an anonymous work to this author that was published in Coimbra in 155 , entitled Incitamentum amoris erga Deum, but there is no 
as Secunda quartae, gained some importance, as it was quoted in commentaries on the Summa by professors from Coimbra and Évora, such as António de São Domingos, ${ }^{120}$ Manuel Tavares, ${ }^{121}$ Pedro Simões, Hernán Pérez, ${ }^{122}$ Molina, ${ }^{123}$ and Suárez, ${ }^{124}$ as well as by authors outside of the university, such as Amador Arrais, ${ }^{125}$ and even beyond Iberia, such as Francisco de Toledo ${ }^{126}$ and Bellarmine. ${ }^{127}$

In contrast to the professors of scholastic theology, the Coimbra professors of the chairs of Sacred Scripture managed to have some of their biblical commentaries printed, and they already enjoyed success beyond the Pyrenees in the 156 os and 1570 s. $^{128}$ The higher number of publications of biblical commentaries produced in Coimbra in comparison to Salamanca can be seen as a reflection of the greater importance that the interpretation of the Bible had in Coimbra - two chairs for the interpretation of the Bible as opposed to one in Salamanca.

evidence for such attribution. On the Sentences commentaries of these two authors, see Lanza and Toste, "The Sentences in Sixteenth-Century", 475-479.

120 See Xavier Monteiro, Frei António, 95 and 324.

121 See Lanza and Toste, "The Sentences in Sixteenth-Century", 476 n. 205.

122 These two Jesuits quoted Martín in their interpretations of $\mathrm{II}^{\mathrm{a}}-\mathrm{II}^{\mathrm{ae}}$, q. 40, see Luis de Molina, Pedro Simões, António de São Domingos, Fernando Pérez, A Escola Ibérica da Paz nas Universidades de Coimbra e Évora (século XVI). Volume 1: Sobre as matérias da guerra e da paz, ed. Calafate, 145, 192, and 392.

123 See Ludovicus Molina, De justitia et jure, tomus II, coll. 66 (tractatus 2, disputatio 266); tomus V, coll. 1321-1322 (tractatus IV, disputatio 33), 1343 (disputatio 37), 1413-1416 (disputatio 51).

124 See Lanza and Toste, "The Sentences in Sixteenth-Century", 476.

125 See Marcocci, “' ‘... per capillos adductos ad pillam'. Il dibattito cinquecentesco sulla validità del battesimo forzato degli ebrei in Portogallo (1496-1497)", 407 and "Remembering the Forced Baptism of Jews: Law, Theology, and History in Sixteenth-Century Portugal”, 348-349.

126 Toledo quoted him in the discussion of restitution, see Franciscus Toletus, In Summam theologiae $S$. Thomae Aquinatis enarratio ... tomus $\mathrm{II}, \mathrm{II}^{\mathrm{a}}-\mathrm{II}^{\mathrm{ae}}, \mathrm{q} .62$, art. $2-3$, and $5-6,253$, $269,276,287$, and $300-301$.

127 Bellarmine quoted Ledesma in several works (Tractatus de potestate summi pontificis in rebus temporalibus and De sacramentis in genere). See, for instance, Robertus Bellarminus, De indulgentiis, 111.

128 The most notable case is that of Hieronymite Heitor Pinto, whose commentaries were printed in Lyons, Cologne, Antwerp, and Salamanca. His dialogue Imagem da vida christã (1572) was translated into Spanish, Italian, French, and Latin (for his output, see Stegmüller, Filosofia e teologia, 27-28 and Rodrigues, A Cátedra de Sagrada Escritura, 272285). Also, professors such as Pablo de Palacio y Salazar and Luís de Sotomaior had their commentaries published outside Iberia (see Stegmüller, Filosofia e teologia, 22-23 and Rodrigues, A Cátedra de Sagrada Escritura, 137-156, 205-209). 
Perhaps the major difference between Coimbra and Salamanca lies in the publications of Coimbra's earliest professors of theology, Monzón and Juan de Pedraza, two Spaniards who had no ties with Salamanca. Instead of publishing relectiones or works on questions related to the Portuguese empire, as Vitoria did, ${ }^{129}$ these two professors composed works aimed at non-university audiences and preferred to deal with moral theology. It is perhaps no coincidence that just a few years before the publication of Manual de confesores (1549) by the professor of canon law at Coimbra, Martín de Azpilcueta, Francisco de Monzón published a manual for confessors in Lisbon in $1543,{ }^{130}$ and Juan de Pedraza issued his Confesionario muy provechoso in Lisbon in 1546, which came out after he left Coimbra but which was composed during his professorship there. The Confesionario has ten chapters, each dealing with one of the commandments. It drew extensively on Aquinas and Cajetan, ${ }^{131}$ suggesting that the Dominican Pedraza taught along Thomistic lines while in Coimbra. He later published a Summa de casos de conciencia (Valencia, 1565), which enjoyed considerable editorial success. ${ }^{132}$

In contrast, the production of pastoral works by Salamancan theologians came later: Domingo de Soto's Suma de la doctrina cristiana was printed in 1552, Tomás de Chaves's Summa sacramentorum Ecclesiae came out in 1560, and Bartolomé de Medina's Breve instrucción de cómo se ha de administrar el sacramento de la penitencia was published in 1580 . Given that Coimbra published pragmatic literature before Salamanca, ${ }^{133}$ it seems clear that Martín de Azpilcueta's composition of the Manual de confesores has to be seen primarily against the background of Coimbra.

A further distinctive trait comes from other works that Monzón wrote while he was in Coimbra which had no parallel in Salamanca: the composition of mirrors for princes. ${ }^{134}$ Salamanca's first mirror for princes was published quite

129 This does not mean that other professors in Coimbra did not address questions related to Portugal in their lectures, quite the contrary, for they often referred to Portuguese legislation.

130 Its complete title is Norte de confesores compuesto por el doctor de Monçón, predicador del Rey nuestro señor, adonde se tratan las partes que han de tener los sacerdotes que confiesan, y decláranse la orden que han de guardar en sus confesiones y la manera que tendrán en determinar los casos y dudas que allíse ofrecen.

131 See the full list of references at http://filosofia.org/mor/jdp/confcit.htm (retrieved on 13-O3-202O).

132 It went through over 30 editions. On this author and work, see the article by Gustavo Bueno Sánchez, http://filosofia.org/ave/oo3/coo4.htm (retrieved on 13-03-2020).

133 On this notion, see the introduction to this volume.

134 Monzón published the Libro primero del Espejo del príncipe cristiano in 1544 in Lisbon (second edition in 1571). The Libro segundo was published only recently in 2012 (Francisco de Monzón, Libro segundo del Espejo del perfecto príncipe cristiano, ed. C. Fernández 
late by Juan Márquez, who wrote El governador christiano (1612) while he held the vespers chair.

When Martín de Ledesma was appointed to the vespers and later to the prima chair, the kind of pragmatic literature nurtured by Monzón and Pedraza stopped being produced in Coimbra, at least by professors of scholastic theology. In contrast, Azpilcueta continued to follow that path in canon law and, in 1557, a professor of Sacred Scripture, Pablo Palacio y Salazar, published a Portuguese translation, with annotations, of the Summa Caietani. ${ }^{135}$ This work had a good reception, being quoted outside the Iberian Peninsula. As already noted, the Summa Caietani became central in the instruction at Évora from the 156os onwards, and the publication of this work probably reveals a growing interest in that work in Portugal.

Unlike the professors of Salamanca and Coimbra, the professors of Évora did not publish anything until the 159os: they simply concentrated on their academic lectures. The only exception seems to be the catechism, Doutrina Cristã, by Marcos Jorge, which was later revised by Inácio Martins and first published in the 156 os. ${ }^{136}$ This work became the basis for the Jesuit missionary work in the Portuguese colonies and was translated into Tamil, Canarese Brahmin, Konkani, Kikongo, Japanese, and Tupi.

Moreover, unlike in Salamanca and Coimbra, the proceedings of the academic meetings in which the subjects of study for the following academic year were decided in Évora have not came down to us. In order to know what was taught in each chair, we have to rely on manuscripts containing the lectures of each professor which contain a precise date. In spite of these limitations, we can draw some conclusions. As in Salamanca and Coimbra, Évora's professors read every part of the Summa. There was, however, a certain tendency to read the $\mathrm{II}^{\mathrm{a}}-\mathrm{II}^{\mathrm{ae}}$ in the prima chair more often, and to spend more time reading it. For instance, Molina read the $\mathrm{I}^{\mathrm{a}}$ from November 1570 to August 1573, but he then lectured for seven academic years on the $\mathrm{II}^{\mathrm{a}}-\mathrm{II}{ }^{\text {ae }} .137$ Likewise, Pero-Luis Beuther read the first 73 questions of the $\mathrm{I}^{\mathrm{a}}$ in three academic years (from 1584 to July 1587), while he took four academic years $(1579-1583)$ in the vespers chair

Travieso) and the Libro primero del espejo de la princesa was published in 1997 (Marques da Silva, J.M., O libro primero del espejo de la princesa christiana de Francisco de Monzón. Imagens da princesa e da dama na corte modelar de João III).

135 Summa Caietana trasladada en lingoajem portugues com annotações de muytas duuidas e casos de conscientia, Lisbon, 1557 . It was reprinted in Coimbra (1560 and 1566).

136 On these two professors, see later in this chapter.

137 He read the $\mathrm{II}^{\mathrm{a}}-\mathrm{II}^{\text {ae }}$ in $1573^{-1575}$ and in ${ }^{1577-1582}$. He did not teach in ${ }^{1575^{-1}}{ }^{-157}$. See Stegmüller, Filosofia e teologia, 43. 
to read just the first $3^{2}$ questions of the $\mathrm{II}^{\mathrm{a}}-\mathrm{II}^{\mathrm{ae}}$. And in $1591-1592$, he read the first 24 questions of the $\mathrm{I}^{\mathrm{a}}$, which further shows that his pace was slower on the $\mathrm{II}^{\mathrm{a}}-\mathrm{II}{ }^{\text {ae }}{ }^{138}$ It is more difficult to reconstruct the teaching careers of later holders of the prima chair, but some figures are suggestive. For instance, António Carvalho (1594-1598) left no commentary on the $\mathrm{I}^{\mathrm{a}}$, but his lectures on the $\mathrm{I}^{\mathrm{a}}{ }_{-}$ $\mathrm{II}^{\text {ae }}$ survive partially in two manuscripts, on the $\mathrm{II}^{\mathrm{a}}-\mathrm{II}^{\text {ae }}$ in eight manuscripts, and on the III ${ }^{\mathrm{a}}$ in three manuscripts. ${ }^{139}$ By contrast, in the vespers chair and in the third chair of theology, there was a slight tendency to lecture more on the I $^{\mathrm{a}}$-I I ${ }^{\text {ae }}, 140$ though here, too, all parts of the Summa seem to have been covered.

The works that resulted from the classes of cases of conscience were different. As noted earlier, many of them consisted of commentaries on the Summa Caietani (though this changed by the end of the 16th century). The Summa Caietani, whose original title was Summa peccatorum, was intended as a handbook for confessors. It is arranged alphabetically and deals with numerous kinds of sins and some of the sacraments - the longest section of the whole work is in fact on excommunication. It also has a long section on restitution. To our knowledge, Évora and the other Jesuit colleges in Portugal alone produced commentaries on the Summa Caietani: there are no records or evidence of such commentaries produced elsewhere. In this respect, these commentaries are the only witnesses we have to help us understand what really happened in the classes of cases of conscience. Up until now scholars have only ascertained which work was used, but not how that work was read and commented on.

The Portuguese Jesuit commentaries on the Summa Caietani are rather short texts as they never covered Cajetan's whole text, but only one specific section. This is mirrored in their titles: De excommunicatione iuxta Caietanum, De beneficiis super Caietanum, De fama iuxta Caietanum, ${ }^{141}$ De ieiunio iuxta

138 For the dates of his theological lectures, see Reinhardt, Pedro Luis SJ (1538-1602) und sein Verständnis der Kontingenz, $16-18$ and 25-39.

139 See Stegmüller, Filosofia e teologia, 49. The holders of the prima chair, Estêvão de Couto (1598-16o8) and Baltasar Álvares (1608-1617) commented on the $\mathrm{I}^{\mathrm{a}}$.

140 There are commentaries on the $\mathrm{I}^{\mathrm{a}}-\mathrm{II}^{\mathrm{ae}}$ made in the vespers chair by Molina (1568-1570), Inácio Martins (1570, substituting for Molina), Pero-Luis Beuther (1575-1576), Pedro Novais (1595), Nicolau Godinho (1597 and 1599), and Francisco da Costa (1610). In the third chair, lectures on the I ${ }^{\mathrm{a}}-\mathrm{II}^{\mathrm{ae}}$ were given by Gaspar Gonçalves, Francisco Pereira (1586-1587), Luís de Cerqueira (January-July 159o), and Gaspar Vaz (1592). See Stegmüller, Filosofia e teologia, 52-6o, Díez-Alegría, El desarrollo de la doctrina de la ley natural en Luis de Molina y en los maestros de la Universidad de Évora de 1565 a 1591, 34, 38, and 42-45.

141 These are the titles of works by Diogo Álvares Cisneiros, holder of the prima chair of cases of conscience between 1569 and 1573 . He later became professor at the Roman College, which is a further hint of the influence that Évora possibly played in matters concerning the teaching of cases of conscience, see Stegmüller, Filosofia e teologia, 65-66. 
Summa Caietani, ${ }^{142}$ and De homicidio secundum Caietanum. ${ }^{143}$ Some other texts by Portuguese Jesuit authors are not commentaries on Cajetan, but works on the Decalogue or summaries of the doctrine on very specific topics, with titles like De usura, De furto, De voto, De restitutione, De homicidio, and De iuramento. Many of these texts were transmitted in more than one manuscript, revealing that they circulated among Jesuit colleges. Furthermore, they are preserved in manuscripts containing more than 20 texts of this kind. These manuscripts are true collections of texts authored by different professors and they form true handbooks. This is plain to see in the manuscripts Biblioteca Nacional, Lisbon, COD. 2362, which contains 39 texts, whose titles often begin Ex materia, and Biblioteca Nacional, Lisbon, COD. 3858, with 11 texts, all of them related to classes taught at the Jesuit college of Lisbon. ${ }^{144}$ These manuscripts gather texts from the teaching at Évora as well as Coimbra and Lisbon. They did not come directly from classroom lectures, as the handwriting is polished, but rather they are probably revised versions of the original lectures and therefore could be used as a guide in the classroom too. Both of the commentaries on Cajetan and the other texts deal with topics that are found in the $\mathrm{II}^{\mathrm{a}}-\mathrm{II}^{\mathrm{ae}}$ and in the $\mathrm{III}^{\mathrm{a}}$ of the Summa theologiae. By leaving out the $\mathrm{I}^{\mathrm{a}}-\mathrm{II}^{\mathrm{ae}}$, the lectures on cases of conscience omitted virtue ethics and all the medieval reflection on the moral virtues and passions. Finally, it would be too restrictive to think of these works as mere compendia. To give just one example, Pedro Simões's De restitutione is a long, cohesive work consisting of lectures given in the College of Lisbon during an entire year, from February 1577 to February $1578 .{ }^{145}$

But how can we relate these works to Salamanca, or, in other words, what is their relevance to the analysis carried out in this chapter? When one examines their structure and content, it comes as a surprise that, although they were related to a course of study called cases of conscience, they did not deal with particular and concrete cases, as happened in handbooks for confessors. Instead, these works are a condensation of the current doctrine and scholastic literature. Furthermore, they were also connected to their social reality, as

142 This is a work by Gaspar Fernandes, holder of the prima chair in 1591, see Stegmüller, Filosofia e teologia, 68.

143 This is a work by Pedro Martins, professor in the vespers chair of cases of conscience in 1571-1572, see Stegmüller, Filosofia e teologia, 53 .

144 See the descriptions in Stegmüller, Filosofia e teologia, 110-112 and 163-164. Stegmüller's description of COD. 2362 is flawed since there are more texts than he indicated.

145 It is preserved in the Biblioteca Nacional, Lisbon, COD. 3858 , fols. 1r-159v, Biblioteca Nacional, Lisbon, COD. 2362, fols. 67v-98r. 
they sometimes referred to Portuguese legislation. ${ }^{146}$ Their structures vary, but typically they are arranged in question-and-answer format. Occasionally, they repeat Cajetan but often they expand his views: in this case, a great part of the answer was a list of quotations from auctoritates. After Cajetan, the most quoted authors in these texts are Aquinas, Sylvester Mazzolini, Azpilcueta, Vitoria (his relectiones), Soto, Alfonso de Castro, and Covarrubias. ${ }^{147}$ These writings can therefore be seen as important channels for the transmission of the thought produced in Salamanca. Whether, in transmitting, they also changed that thought remains to be investigated in the future. ${ }^{148}$ These works are also important because they anticipated what the Ratio studiorum, whether in the 1586 draft or in its final version, would establish regarding the way in which cases of conscience should be taught and how it should use the works and opinions of theologians and canonists. ${ }^{149}$ One of the members of the committee charged with the redaction of the Ratio was Gaspar Gonçalves, as mentioned above, and it is possible that he gave some input from his experience in Évora.

The teaching of cases of conscience underwent an important transformation in Évora in the late 158 os or the beginning of the 159os. Apparently, the Summa Caietani was no longer used. From that moment on, the holders of the two chairs of cases of conscience began to do one of the following: they either lectured on the Summa theologiae, though only on sections of the $\mathrm{II}^{\mathrm{a}}-\mathrm{II}^{\mathrm{ae}}$ or the III $^{\mathrm{a}}$ - as was the case of Nicolau Pimenta in the prima chair (c. 1585) -, ${ }^{150}$ or built up lengthy treatises on juridical topics which were loosely connected with the Summa. In this respect, they bear witness to what we might call a "juridification" of theology, since they approached mostly legal issues. The faculty of cases of conscience then became the place not of moral theology - as cases of conscience came to be called in the 17th century - but of what we

146 This was the case in Pedro Simões's De restitutione, which was made in 1577 at the College of Lisbon. He mentioned Portuguese legislation twice. See Biblioteca Nacional, Lisboa, COD. 2362 , fols. $67 \mathrm{v}-98 \mathrm{r}$, at fols. 8 ov and $84 \mathrm{v}$.

147 A striking example of this is Marcos Jorge's De vectigalibus seu tributis super Caietanum, verbum Vectigal, a doctore Marco Giorgio, anno Domini 1567, calendis dezembris Olyssiponi (Biblioteca Nacional, Lisbon, COD. 3858 , fols. 289r-297r). This rather short work is condensed in Biblioteca Nacional, Lisbon, COD. 3982, fols. 67v-69v. This condensation consists in the elimination of quotations. Jorge was the first holder of the prima chair of cases of conscience in Évora (1559-1564).

148 We are preparing a publication about these works in which we include their tabulae quaestionum.

149 See Theiner, Die Entwicklung, 154-158 and Angelozzi, "L'insegnamento dei casi di coscienza", $155^{-158 .}$

150 See Stegmüller, Filosofia e teologia, 71. 
might call "juridical theology" or, to use Wim Decock's expression, "moral jurisprudence". ${ }^{151}$ This is evident in the works of Fernão Rebelo (prima chair, 15891596), Gaspar de Miranda (prima chair, 1597-1604), Sebastião do Couto (prima chair, 1610-1616), Marco Vicente (professor in the second chair), and Francisco da Veiga (second chair, 1607-1611). ${ }^{152}$

It is insufficient to state that these works emphasised juridical questions: rather, they focused exclusively on such questions. Beyond topics like usury and restitution, which had long been dealt with in theology, we find extensive treatises on contracts, the constitution of partnerships (societates), gambling, and testaments. One can find the exact same stress on these topics in Molina's De iustitia et iure, which came from his lectures in the prima chair of theology in Évora and which was published at the same time these lectures were being given in Évora (six volumes: 1593-16o9). Of all the works produced by professors of cases of conscience, only one was printed, Fernão Rebelo's De obligationibus iustitiae, religionis et caritatis (Lyons, 1608). ${ }^{153}$

If we recall that Soto's De iustitia et iure was issued 40 years prior to Molina's work and followed the order of Aquinas's Summa step-by-step, then we get the sense of the dramatic distance between the beginnings of the "School of Salamanca" and the works produced in Évora by the end of the century. As has been emphasised, Molina himself declared that Aquinas's treatise De iustitia et iure was inadequate, since Aquinas had not dealt with many topics. ${ }^{154}$ Of course, this "juridical turn" has to be associated with the Counter-Reformation and the attempt to discipline man's conscience by providing clear guidelines in all fields of human action, that is, a sort of "theory of practice". 155 However, what is important to remark upon here is the role played by Évora in that juridical turn, since these Jesuits preceded authors like Lessius and Tomás Sánchez, the more popular objects of academic study so far. To give an idea of the distance between Évora and Salamanca, by the end of the 16th-century Salamancan theologians were still lecturing on the Summa with the approach that had been launched by Vitoria and Soto, and, in 1585, even a Jesuit professor in Salamanca, Francisco de Buenaventura, was reading the $\mathrm{II}^{\mathrm{a}}{ }_{-\mathrm{II}}{ }^{\mathrm{ae}}$ in traditional terms. ${ }^{156}$ By contrast, as early as 1570 , the lectures on the Summa given in

$15^{1}$ See Decock, Theologians and Contract Law, 55-56 and 647.

$15^{2}$ For all these professors of Évora, see Stegmüller, Filosofia e teologia, 69-70, 71-72, 74, and $75^{-76}$.

153 It has been studied in Decock, Theologians and Contract Law, 259-263 and 305-308.

154 See in Decock, Theologians and Contract Law, 65-66.

155 See the fourth section of the introduction to this volume.

156 See, for instance, his commentary on the $\mathrm{II}^{\mathrm{a}}-\mathrm{II}^{\mathrm{ae}}$, qq. $1-31$, which is preserved in the codex Biblioteca Universitaria, Salamanca (BUS), 695, fols. 1r-377v. 
Évora contained more quotations from juridical works than the lectures given in Salamanca. ${ }^{157}$

\section{Conclusion (with a Sample of Salamanca's Doctrinal Influence)}

This chapter has highlighted the similarities and differences between the three universities studied here. Undoubtedly Coimbra maintained closer ties to Salamanca than Évora did. When it comes to the teaching of scholastic theology, this was due to the role played by Martín de Ledesma and the Dominicans in Coimbra, who were able to impose the Summa as the textbook. But further research is needed to assess the doctrinal influence - and this is what matters - of specific authors, such as Vitoria or Soto, over specific authors from other universities, otherwise, we risk falling into vague generalisations. In this sense, it is meaningless to assert that Salamanca influenced Coimbra or Évora if we do not examine specific authors and ideas. Not every Salamancan author subscribed to every idea from Vitoria's or Soto's theories and the same applies to Coimbra and Évora. ${ }^{158}$ Such research exceeds the scope of this article, but a very short example of how that influence happened serves both as a springboard for further research and, principally, as the only means to corroborate what has been argued throughout this chapter.

The fact that the greater part of the lectures produced in these universities remains unpublished explains the scarcity of studies on the influence of Salamanca over other Iberian universities. On the other hand, since the lectures were part of the same commentary tradition - on the Summa theologiae - it is not too difficult to trace influences, for the same arguments and sources often ran across the commentary tradition and the later commentaries drew on the earlier ones. There is, however, a divide in the commentary tradition: the moment, starting in the late 1570s, when the commentaries on the Summa by Medina, Báñez, Zumel, and Aragón were printed. As noted earlier, at that point, the circulation of manuscripts diminished dramatically, although it did not stop completely and academic manuscripts were still circulating in

157 This is evident in the lectures given by Inácio Martins (see the next pages). Commenting on the $\mathrm{I}^{\mathrm{a}}-\mathrm{II}^{\mathrm{ae}}, \mathrm{q} .96$, he quoted Bartolus of Saxoferrato and Panormitanus abundantly.

${ }_{15} 8$ For instance, in the interpretation of $\mathrm{II}^{\mathrm{a}}-\mathrm{II}^{\mathrm{ae}}, \mathrm{q} .26$, art. 4, from Sotomayor onwards, the Salamancan professors opposed Vitoria and Soto over the idea that one may not sacrifice his own eternal salvation for the sake of others and followed Capreolus instead. On this, see Toste, "Between Self-Preservation and Self-Sacrifice: The Debate in Sixteenth-Century Scholasticism". 
the early 17 th century. ${ }^{159}$ But from that moment on, references to unpublished commentaries became very rare. For example, in commentaries made after the publication of the commentaries of Medina, Báñez, Zumel, and Aragón, we find explicit references to these four authors whereas there is a total absence of references to authors like Sotomayor, Mancio, and Peña. ${ }^{160}$ In this regard, it is easy to assess the influence of the printed works. By way of example, a text such as Vitoria's Relectio de iure belli had an overwhelming presence in the interpretations of $\mathrm{II}^{\mathrm{a}}-\mathrm{II}^{\mathrm{ae}}, \mathrm{q} .4 \mathrm{O}$ (De bello) produced in Coimbra and Évora, and his other relectiones were profusely quoted in the commentaries on the Summa Caietani that were written in Évora, Coimbra, and Lisbon. ${ }^{161}$ Conversely, it is quite laborious and challenging to investigate the influence of the Salamancan authors active between 1530 and 1580 who did not publish their lectures - that is, a great part of the authors of the "School of Salamanca", including Vitoria and Soto, if we recall that many of their teachings remain unpublished. But precisely these decades are the ones that have established the tradition of the "School of Salamanca".

The most revealing issues for the study of the influence of Salamanca over authors from other universities are those in which there was disagreement among the major Salamancan theologians, for instance, between Vitoria and Soto or between these two "founders" and later theologians in Salamanca. In such cases, later commentators from other universities typically adopted one view or the other. Let us very briefly examine one such case, the discussion about the law's effect, which occurs in Summa theologiae $\mathrm{I}^{\mathrm{a}}-\mathrm{II}^{\mathrm{ae}}$, q. 92, art. 1.

The discussion on law was at the heart of the interests of the Salamancan theologians. More specifically, in the discussion of the law's effect, Vitoria and

159 See above, the second section.

16o Take the example of Manuel Tavares, the holder of the chairs of Durand (1587-1597) and Scotus (1597-1605) in Coimbra, who left a commentary on Durand's Sentences commentary, Book III, dist. 27-30 (it is preserved in Biblioteca Pública, Évora (В РЕ), СXIX-2-4, fols. 233r-28ov, see Lanza and Toste, "Sixteenth-Century Sentences Commentaries", 259-26o). In his discussion of charity, the only Salamancan authors he quoted were Soto, Báñez, and Aragón (see for instance fol. 215v).

161 For instance, the Relectio de simonia was quoted in the anonymous De simonia (BNL, COD. 5139, fols. 181v-201v); the Relectio de potestate civili was mentioned more than once in the anonymous De legibus et praeceptis (BNL, COD. 2362, fols. 295r-333v); finally, the Relectio de homicidio was quoted in Pedro Simões's De homicidio (BNL, COD. 3858, fols., $320 v-348 \mathrm{v}$ ), produced at the Jesuit College of Lisbon in 1575, in Pedro Martins's De homicidio (BNL, COD. 396o, fols. 115r-134r; BNL, COD. 3970, fols. 373r-395v) and in Diogo Cisneiros's De homicidio (BNL, COD. 2362, fols. 10or-104v; BNL, COD. 3982, fols. 78r-81v). To avoid any misunderstanding, note that Vitoria was mentioned along with Soto and other scholastic authors. 
Soto presented opposing views: while for Vitoria, there could be no distinction between being a good citizen and being a good man, and therefore no one could be a good citizen unless he was a good man and vice versa, Soto subscribed to Aquinas's view that being a good citizen and being a good person were two distinct features. This meant that for Vitoria, the law's effect was to make men good simpliciter, while for Soto, the law made men good only with regard to the application of that law, that is, secundum quid. As has been shown elsewhere, most of the Salamancan theologians followed Vitoria, at least until Medina published his commentary on the $\mathrm{I}^{\mathrm{a}}-\mathrm{II}^{\mathrm{ae}} .{ }^{162}$

The lectures of two Coimbra professors on this question have come down to us, those given by Martín de Ledesma in ${ }^{1547-1548}$ in the vespers chair, ${ }^{163}$ and those given by António de São Domingos in ${ }^{1576-1577}$ in the prima chair.164 In addition, two commentaries that were produced in Évora during the 1570 s have survived in two manuscripts each: one by Inácio Martins, which followed from his lectures in 1570 when he temporarily substituted for Molina in the vespers chair, ${ }^{165}$ and a second, by Gaspar Gonçalves in the third chair of theology in 1579, before he went to Rome. ${ }^{166}$ Finally, the lectures of Bartholomew of Braga (also known as Bartolomeu dos Mártires) in the Dominican convent of Batalha in 1545-1546 (but revised several times until 1555) survived and are available in print. ${ }^{167}$

162 See Toste, "Unjust Laws and Moral Obligation in the Sixteenth-Century Salamancan Commentaries on Thomas Aquinas's De legibus".

163 For the date, see Beltrán de Heredia, "Las relecciones y lecturas", 117 and Rodrigues, "Padres agostinhos", 330. Ledesma's interpretation of q. 92, art. 1, survives in the manuscript BNL, COD. 3635 , fols. $8 \mathrm{v}-9 \mathrm{v}$.

164 For the date, see Xavier Monteiro, Frei António, 106. For q. 92, art. 1, see Biblioteca da Universidade, Coimbra (BUC), 1844 (= T11), fols. 228r-232v.

165 Question 92, art. 1 is in BNL, COD. 2804, fols. $383 \mathrm{v}-384 \mathrm{r}$ and BNL, COD. 3848 , fols. $18 \mathrm{v}-19 \mathrm{r}$. This second codex belonged to the Jesuit college of Angra on Terceira Island (Azores), which suggests that the theological production of Évora circulated in the colleges of the Portuguese empire. This question was published under Molina's name as an appendix to Franciscus Suárez, De legibus (I 9-20): De legibus obligatione, ed. Pereña et al., 227-230. On the commentaries on the $\mathrm{I}^{\mathrm{a}}-\mathrm{II}^{\mathrm{ae}}$ produced in Évora, see Díez-Alegría, El desarrollo de la doctrina. On the life and career of this important Jesuit, see Freitas de Carvalho, "Um pregador em tempos de guerra: Inácio Martins, S.J.: seis sermões contra os ingleses (15881596) e cinco cartas de viagem por Europa (1573-74)".

166 It survives in BNL, COD. 2802 and Biblioteca da Ajuda, Lisbon (BAL), 50-I-68. The first manuscript is in bad condition and we have not been allowed to consult it. In the second manuscript, q. 92, art. 1, is found in fol. $77 \mathrm{r}-\mathrm{v}$. For the attribution of the text contained in Ajuda to Gonçalves, see Díez-Alegría, El desarrollo, 39-41.

167 Bartholomaeus de Martyribus, O.P., Annotationes super ram-2ae, ed. Almeida Rolo, 506-508. 
Let us see diachronically how these five professors commented on q. 92, art. 1. What emerges from a preliminary analysis is that Ledesma endorsed Vitoria's position: for him, civil laws aimed at making men good absolutely, not merely with respect to the range of civil laws, and for this reason, one could not be a good citizen if he was not a good man. Although Ledesma rested upon Vitoria's interpretation of the same question and quoted the same sources (Romans 13:1, Peter 2:13), ${ }^{168}$ he did not reproduce Vitoria's text slavishly (at least, not in the way Beltrán de Heredia showed he did in his commentary on Book IV of the Sentences). The only author Ledesma quoted was Alfonso de Castro (his De potestate lege poenali) for the idea that the law was not intended to make men good absolutely. ${ }^{169}$ By contrast, Bartholomew of Braga clearly depended on Cajetan's commentary - the only author he mentioned,$-{ }^{170}$ and accepted that the virtues of the good man and the good citizen were distinct. ${ }^{171}$ This view was shared by the Jesuit Inácio Martins: in his commentary, he only mentioned Cajetan and Soto's De iustitia et iure, considering that "Soti explicatio magis est ad mentem divi Thomae" [the explanation of Soto is more like the intention of St. Thomas], that is, that civil laws did not necessarily make men good simpliciter; in fact, unjust laws made men only good subjects. ${ }^{172}$ Martins's interpretation was reproduced almost verbatim by his fellow professor in Évora, Gaspar Gonçalves.

For our purposes, more important than the fact that Bartholomew of Braga and Martins (and Gonçalves) followed Cajetan and Soto instead of Vitoria, is that they apparently only quoted (and seemed only to draw on) printed works. For this reason, António de São Domingos's commentary stands out as a very interesting case. At first sight, his interpretation of q. 92, art. 1, seems to side with Vitoria: for him, any law has to make men good simpliciter and every law has to foster moral virtue and not merely political virtue. But a closer analysis shows that a great part of his text was closely based on Luis de León's commentary on Durand's Sentences commentary, Book III, dist. 40, which, despite its title, was actually a commentary on Aquinas's De legibus. ${ }^{173}$ António de São Domingos never mentioned Luis de León, and he slightly changed Luis de

168 See Francisco de Vitoria, Comentarios a la "Secunda Secundae" de Santo Tomás. Tomo VI, ed. Beltrán de Heredia, 421-422.

169 See BNL, COD. 3635 , fols. $8 \mathrm{v}-9 \mathrm{v}$.

170 He made use of Cajetan's commentary, not on $\mathrm{I}^{\mathrm{a}}-\mathrm{II}^{\mathrm{ae}}, \mathrm{q} \cdot 92$, art. 1, but on the $\mathrm{II}^{\mathrm{a}}-\mathrm{II}^{\mathrm{ae}}, \mathrm{q} \cdot 47$, art. 11 .

171 See Bartholomaeus de Martyribus, Theologica Scripta, 507-508.

172 See in Suárez, De legibus, 229.

173 Luis de León's explanation of this question was published in Fray Luis de León, Tratado sobre la ley, 150-166. 
León's view. Luis de León followed Aristotle, distinguishing between the virtue of the good man, the virtue of the good citizen, and the virtue of the good ruler. ${ }^{174}$ However, unlike Aristotle or Aquinas, he conceived of these three virtues as three hierarchical degrees of virtue, in which the superior included the others, while the inferior did not presuppose the superior. The lowest degree was the virtue of the good citizen, followed by the virtue of the good man, and then by the virtue of the good ruler. António de São Domingos used these same ideas, but added another degree of virtue, the virtue of the subject, which consisted in obeying the law. This was the lowest degree of virtue, the other three degrees corresponded to Luis de León's three degrees. ${ }^{175}$ What is striking is that Luis de León's text is preserved in the manuscript Biblioteca da Universidade, Coimbra, $1843(=$ T10), which is part of the set of manuscripts we mentioned in the second section of this article. Is this just a coincidence? Analysis of another question of António de São Domingos's commentary gives us the answer. At the end of q. 95, art. 4, he raised a doubt about the mixed regime, ${ }^{176}$ one that is not found in Luis de León. But, far from being a doubt that he ingeniously raised, it was merely a reproduction of Bartolomé de Medina's explanation of the same question. ${ }^{177}$ Medina's commentary is found in the manuscript Biblioteca da Universidade, Coimbra, $1846\left(=\mathrm{T}_{13}\right)$ - another of the manuscripts of the Coimbra library that contain Salamancan texts. This attests that such a set of Salamancan manuscripts was indeed used by theologians in Coimbra. Luis de León's text was based on lectures he gave in 1570-1571, and Medina's commentary came from lectures he gave in 1574-1575. The use of these lectures by António de São Domingos just a few years later suggests, as mentioned above, that he might have been somehow related to the acquisition of these manuscripts; he was in any case one of the first authors to draw on these two Salamancan professors. ${ }^{178}$

The use of these manuscripts tells us another important thing: when studying the impact of Salamanca, scholars almost always focus exclusively on the role played by Vitoria, Soto, Cano, Medina, and Báñez, neglecting all the other Salamancan theologians whose lectures were not printed in their own

\footnotetext{
174 Toste, "Unjust Laws", 114-115.

175 See BUC, 1844 (= T11), fols. 231v-232v.

176 BUC, 1844 (= T11), fol. 253r.

177 Bartholomaeus a Medina, Expositio in Primam Secundae angelici doctoris divi Thomae, 507.

178 In addition, Xavier Monteiro attempted to show how António possibly drew on Martín de Ledesma's unpublished Sentences commentary and on Báñez's commentary on the $\mathrm{I}^{\mathrm{a}}-\mathrm{II}^{\mathrm{ae}}$, which was available to him only in manuscript form. See Xavier Monteiro, Frei António, 166, 175, and 185 .
} 
time. But the example of António de São Domingos tells us that Luis de León and Bartolomé de Medina (even before the publication of his commentary) were also influential, and, in this case, more so than Vitoria and Soto. Was António de São Domingos an exceptional case in this regard? It does not seem so. In the lectures he taught in the Roman College in 1566-1567, Francisco de Toledo - always remembered by scholars as a pupil of Soto - quoted Soto's printed works and also the unpublished lectures of Juan de la Peña. ${ }^{179}$

A full study of the impact of Salamancan thought is yet to be carried out and it would be an oversimplification to assume that the way in which António de São Domingos drew on Salamancan authors extended to the interpretation of every article of the Summa carried out by every professor in Coimbra and Évora. As our sample suggests, the professors in Évora made use chiefly of printed texts. This could be related to the paucity of manuscripts containing Salamancan texts in the library of Évora. In his study of the notion of natural law in the lectures of Évora professors, Díez-Alegría showed that, while Ledesma was influenced by Vitoria, the Évora Jesuits, starting with Hernán Pérez, instead followed Soto's De iustitia et iure; once again, the influence came from a printed work. ${ }^{180}$ However, this is not to say that professors in Évora did not draw on manuscripts at all. In his lectures on the II $^{\mathrm{a}}-\mathrm{II}^{\mathrm{ae}}$, Molina displayed a good knowledge of the arguments found in the commentaries produced in Salamanca, and in one question of the $\mathrm{I}^{\mathrm{a}}-\mathrm{II}^{\mathrm{ae}}$, Inácio Martins held views very close to those of Martín de Ledesma's unpublished commentary on $\mathrm{I}^{\mathrm{a}}-\mathrm{II}^{\mathrm{ae}}$, qq. 9O-114. ${ }^{181}$

It seems, therefore, that the impact of Salamanca on Coimbra and Évora occurred in distinct ways. Future research will better establish the relationship between authors from these three universities, although this will only be possible by examining a vast array of topics. ${ }^{182}$ What perhaps needs to be borne in mind is that Salamanca was not the only influential university in the Iberian

179 Franciscus Toletus, In Summam theologiae, $\mathrm{II}^{\mathrm{a}-\mathrm{II}^{\mathrm{ae}}}$, q. 3, art. 1, 89, "Ita tenent ... et frater Ioannes Pegna in sua lectura. Argumentum huius est ...".

180 See Díez-Alegría, El desarrollo de la doctrina, 73-75 (for Ledesma), 130-137 (on how Pérez followed Soto faithfully), and 159-176, 181 (for Molina and other professors on the immutability of natural law).

181 For Molina, see Toste, "Between Self-Preservation", pp. 385-386 and for Martins, see DíezAlegría, El desarrollo de la doctrina, 69-75.

182 Because so far only a few topics have been studied, it is pointless to draw general conclusions. For instance, in Stegmüller, Geschichte des Molinismus, 30*, Reinhardt, Pedro Luis SJ, 221, and Díez-Alegría, El desarrollo de la doctrina, 130-137, it is claimed that Hernán Pérez was a theologian with conservative leanings and a follower of Soto. However, Pérez on occasion clearly rejected Soto's views, even to the extent of deriding him, in which he was followed by his fellow professor from Évora, Fernão Rebelo. See Lanza, "Si peccavit per hoc quod fregit ostium, páguelo!: The Debate on Whether the Prisoner Condemned 
Peninsula. As we have seen, men and works from Alcalá were also present in Portugal, ${ }^{183}$ and the Coimbra professors of Sacred Scripture had more ties to Paris and Leuven than to Salamanca. The relationship between Coimbra and Évora was also quite strong: Molina, Pérez, and Simões studied and/or taught in Évora and in the Jesuit college of Coimbra, and the same happened with all the authors of the famous Cursus Conimbricensis. Despite their differences, these universities formed a network of men, texts, and ideas, or, as noted in the introduction to this volume, an epistemic community in which men interchanged ideas and information. For this reason, while this chapter has focused on the influence of Salamanca, future research will also need to assess the impact that men from Coimbra and Évora - like Martín de Ledesma, Molina, and later Rebelo - might have had in Salamanca. ${ }^{184}$ Only in this way will we avoid thinking of Salamanca as a kind of island.

\section{Bibliography}

\section{Manuscripts}

Arquivo da Universidade, Coimbra (AUC), Estatutos da Universidade de Évora (1563), U. Évora 2, U. Évora 3. AUC, Estatutos da Universidade de Évora (1567), U. Évora 4. Biblioteca da Universidade, Coimbra (BUC), Statutos da Vniversidade de Coimbra confirmados por el Rey Dom Philippe Primeiro deste nome, nosso senor em o anno de 1597, ms 1002.

\section{Printed Sources}

Cartularium de la Universidad de Salamanca (1218-16oo), ed. Beltrán de Heredia, Vicente, Salamanca 1972, tomo 4.

Estatutos da Universidade de Coimbra (1559), ed. Leite, Serafim, Coimbra 1963.

Estatutos da Universidade de Coimbra. Confirmados por el Rei Dom Phelippe primeiro deste nome, nosso Senhor, em o anno de 1591, Coimbra 1993.

to Death Can Lawfully Escape in the 16th-Century Commentary Tradition on the Summa Theologiae", pp. 417-419 and Toste, "Between Self-Preservation", p. 385.

183 Scholars have paid so much attention to Salamanca that the importance of Alcalá for sixteenth-century thought has been completely ignored. To give but one example: no study has ever been carried out on the influence of the famous Alcalá professor, Juan de Medina, on other Iberian authors, despite his importance.

184 By the late 16th century, Martín de Azpilcueta was quoted by Báñez, but again this was through a printed work. 
Estatutos da Universidade de Coimbra (1653). Edição fac-similada, Coimbra 1987.

Estatutos da Universidade de Évora (1570), [ms Biblioteca Pública, Évora, CXIV-231] ed. Marques Pereira, Sara and Francisco Lourenço Vaz, Antologia de textos da Universidade de Évora, CD-Rом appendix to Marques Pereira, Sara and Francisco Lourenço Vaz (eds.), Universidade de Évora (1559-2009): 450 anos de modernidade educativa, Lisboa 2012.

Estatutos da Universidade de Évora ... revistos por ordem do Reverendo Padre Mutio Vitelleschi, prepósito geral da Companhia de Jesus, [ms Biblioteca Nacional, Lisbon COD. 8014] ed. Rosa, Teresa, in Rosa, Teresa, História da Universidade teológica de Évora (séculos XVI a XVIII), Lisboa 2013, Apêndice de documentação anexa, Anexo 1 ${ }^{\circ} 5^{-259}$.

Estatutos hechos por la muy insigne Universidad de Salamanca, año 1561, Salamanca 1561. Estatutos hechos por la muy insigne Universidad de Salamanca, Salamanca 1595.

Monumenta Pedagogica Societatis Iesu. Nova editio penitus retractata. III (1557-1572)**, ed. Lukács, Ladislaus, Roma 1974.

Bellarmino, Roberto, De indulgentiis, in Bellarmino, Roberto, Opera omnia. Tomus V, Palermo / Paris 1872: Pedone Lauriel.

Guevara, o.s.A., Juan de, La fe, la esperanza y la caridad. Comentarios teológicos salmantinos (1569-72). Texto latino, ed. Bermejo Jericó, Ignacio, Madrid 2009.

León, Luis de, Tratado sobre la ley, ed. Barrientos García, José, trans. and revision Fernández Vallina, Emiliano, Real Monasterio de El Escorial 2005.

León, Luis de, Dios y su imagen en el hombre. Lecciones inéditas sobre el libro I de las "Sentencias" (1570), ed. Orrego, Santiago, Pamplona 2008.

Mártires, O.P., Bartolomé dos, Annotationes super ram-2ae, ed. Almeida Rolo, Raúl, Theologica Scripta 2. Annotationes super 1am-2ae, Braga 1973.

Medina, Bartolomé de, Expositio in Primam Secundae angelici doctoris divi Thomae, Salamanca 1580: Jean and André Renault.

Molina, Luis de, Pedro Simões, António de São Domingos, Fernando Pérez, A Escola Ibérica da Paz nas Universidades de Coimbra e Évora (século XVI). Volume 1: Sobre as matérias da guerra e da paz, ed. Calafate, Pedro, Coimbra 2015.

Molina, Luis de, De justitia et jure, 5 vols., Mainz 1659: Schönwetter.

Monzón, Francisco de, Libro primero del Espejo del príncipe cristiano, Lisboa 1544: Luis Rodríguez.

Monzón, Francisco de, Libro primero del espejo de la princesa, ed. Marques da Silva, José Manuel in Marques da Silva, José Manuel, O libro primero del espejo de la princesa christiana de Francisco de Monzón. Imagens da princesa e da dama na corte modelar de João III [MA thesis, University of Porto], Porto 1997.

Monzón, Francisco de, Libro segundo del Espejo del perfecto príncipe cristiano, ed. Fernández Travieso, Carlota, A Coruña 2012.

Polanco, Juan Alfonso de, Chronicon Societatis Iesu. Vita Ignatii Loiolae et rerum Societatis Jesu historia, vol. 3, 6 vols., Madrid 1895: Agustín Avrial. 
Suárez, Francisco, De legibus (I 9-20): De legibus obligatione, ed. Pereña, Luciano et al., Madrid 1972.

Toledo, Francisco, In Summam theologiae S. Thomae Aquinatis enarratio ... tomus II, Roma 1869: Congregatio de Propaganda fide.

Vio, Tommasso di, Summa Caietana trasladada en lingoajem portugues com annotações de muytas duuidas e casos de consciencia por ho Doctor Paulo de Palacio cathedratico da S. Scriptura na vniuersidade de Coimbra, Lisboa 1557: João Blávio de Colonia.

Vitoria, Francisco de, Comentarios a la "Secunda Secundae" de Santo Tomás, Tomo VI, 6 vols., ed. Beltrán de Heredia, Vicente, Salamanca $195^{2}$.

\section{Literature}

Aldama, José Antonio de, "Manuscritos teólogicos postridentinos de la Biblioteca Municipal de Porto", in Archivo Teológico Granadino 1 (1938), 7-26.

Andrés Martín, Melquíades, Historia de la teología en España (1470-1570). 1: Instituciones teológicas, Roma 1962.

Andrés Martín, Melquíades, "Las facultades de teología en las universidades españolas (1396-1868)", in Revista Española de Teología 28 (1968), 318-358.

Angelozzi, Giancarlo, "L'insegnamento dei casi di coscienza nella pratica educativa della Compagnia di Gesù", in Brizzi, Gian Paolo (ed.), La "Ratio studiorum". Modelli culturali e pratiche educative dei Gesuiti in Italia tra Cinque e Seicento, Roma 1981, 121-162.

Barrientos García, José, "Bartolomé de Medina, O.P. y la Universidad de Salamanca”, in Ciencia Tomista 207 (1980), 251-288.

Barrientos García, José, Fray Luis de León y la Universidad de Salamanca, Madrid 1996.

Barrientos García, José, “La teología, siglos XVI-XVII”, in Rodríguez-San Pedro Bezares, Luis Enrique (ed.), Historia de la Universidad de Salamanca. Volumen 3.1: Saberes y confluencias, Salamanca 2006, 203-250.

Barrientos García, José, La Facultad de Teología de la Universidad de Salamanca a través de los Libros de Visitas de Cátedras (1560-1641), Madrid 2018.

Batllori, Miguel, "El teólogo Pedro-Luis Beuther. Sus primeros años: 1538-1558", in Archivum Historicum Societatis Iesu 36 (1967), 126-140.

Becker, Karl Josef, “Tradición manuscrita de las Prelecciones de Domingo de Soto", in Archivo Teológico Granadino 29 (1966), 125-18o.

Belda Plans, Juan, "San Juan de Ribera y la Escuela de Salamanca", in Teología en Valencia: raíces y retos: buscando nuestros orígenes, de cara al futuro. Actas del $X^{o}$ Simposio de Teología Histórica (3-5 marzo 1999), Valencia 200o, 125-138.

Belda Plans, Juan, La Escuela de Salamanca y la renovación de la teología en el siglo XVI, Madrid 2000, 827-852.

Beltrán de Heredia, Vicente, Los manuscritos del maestro Fray Francisco de Vitoria, O.P.: estudio crítico de introducción a sus Lecturas y Relecciones, Madrid 1928. 
Beltrán de Heredia, Vicente, "Los manuscritos de los teólogos de la Escuela Salmantina”, in Ciencia Tomista 42 (1930), 327-349.

Beltrán de Heredia, Vicente, Miscelánea Beltrán de Heredia. Colección de artículos sobre historia de la teología española, 4 vols., Salamanca 1971-1973.

Beltrán de Heredia, Vicente, "El maestro Juan de la Peña, O.P.", in Beltrán de Heredia, Vicente, Miscelanea Beltrán de Heredia, vol. 2, Salamanca 1972, 447-542.

Beltrán de Heredia, Vicente, “El maestro Mancio de Corpus Christi, O.P.", in Beltrán de Heredia, Vicente, Miscelanea Beltrán de Heredia, vol. 2, Salamanca 1972, 363-446.

Beltrán de Heredia, Vicente, "Las relecciones y lecturas de Francisco de Vitoria en su discípulo Martin de Ledesma, O.P.”, in Beltrán de Heredia, Vicente, Miscelánea Beltrán de Heredia, vol. 2, Salamanca 1972, 113-136.

Beltrán de Heredia, Vicente, "La Facultad de Teología en la Universidad de Sigüenza", in Beltrán de Heredia, Vicente, Miscelánea Beltrán de Heredia, vol. 4, Salamanca 1973, 7-59.

Brandão, Mário, Documentos de D. João III, 4 vols., Coimbra 1937-1941.

Brandão, Mário, "A livraria do P. Francisco Suárez", in Brandão, Mário, Estudos vários. Vol. 1, Coimbra 1972.

Bueno Sánchez, Gustavo, "Juan de Pedraza OP $\approx 1500-1567$ ", in http://filosofia.org/ave/ oo3/co04.htm (retrieved on 13.03.2020).

Casalini, Cristiano, Aristotele a Coimbra. Il Cursus Conimbrincensis e l'educazione nel Collegium Artium, Roma 2012.

Decock, Wim, Theologians and Contract Law: The Moral Transformation of the Ius Commune (ca.1500-1650), Leiden / Boston 2013.

Delgado, Inmaculada, "Manuscritos de las reportationes de los Comentarios a la Prima Pars de Francisco de Vitoria", in Helmantica 192 (2013), 265-288.

Díez-Alegría, José María, El desarrollo de la doctrina de la ley natural en Luis de Molina y en los maestros de la Universidad de Évora de 1565 a 1591: estudio histórico y textos inéditos, Barcelona 1951.

Ehrle, Franz, "Los manuscritos vaticanos de los teólogos salmantinos del siglo XVI: de Vitoria a Báñez", in Estudios eclesiásticos 8 (1929), 145-172.

Freitas de Carvalho, José Adriano, "Um pregador em tempos de guerra: Inácio Martins, S.J.: seis sermões contra os ingleses (1588-1596) e cinco cartas de viagem por Europa (1573-74)", in A Companhia de Jesus na Península Ibérica nos sécs. XVI e XVII: espiritualidade e cultura. Actas do colóquio internacional, Maio de 2004. Volume 1, Porto 2004, 231-368.

García Sánchez, Justo, "Relaciones académicas entre Coimbra y Salamanca: un legista, Arias Piñel, y un canonista, Juan Perucho Morgovejo”, in Rodríguez-San Pedro Bezares, Luis Enrique and Juan Luis Polo Rodríguez (eds.), Universidades clásicas de la Europa mediterránea: Bolonia, Coimbra y Alcalá. Miscelánea Alfonso IX, 2005, Salamanca 2006, 139-193. 
Gómez Hellín, Luis, “Toledo, lector de filosofía y teología en el Colegio Romano”, in Archivo teológico granadino 3 (1940), 7-18.

Guitarte Izquierdo, Vidal, Un canonista español en Coimbra: el doctor Juan de Mogrovejo (1509?-1566), Paris 1971.

Llamas Martínez, Enrique, Bartolomé de Torres: teólogo yobispo de Canarias, Madrid 1979. Lanza, Lidia, "Si peccavit per hoc quod fregit ostium, páguelo!: The Debate on Whether the Prisoner Condemned to Death Can Lawfully Escape in the 16th-Century Commentary Tradition on the Summa Theologiae", in Lanza, Lidia and Marco Toste (eds.), Summistae: The Commentary Tradition on Thomas Aquinas' Summa Theologiae from the 15th to the 17th Centuries, Leiden / Boston 2021, 393-424.

Lanza, Lidia, and Marco Toste, "The Sentences in Sixteenth-Century Iberian Scholasticism", in Rosemann, Phillip W. (ed.), Mediaeval Commentaries on the Sentences of Peter Lombard, volume 3, 3. vols., Leiden / Boston 2015, 416-503.

Lanza, Lidia, and Marco Toste, "Sixteenth-Century Sentences Commentaries from Coimbra: The Structure and Content of Some Manuscripts", in Studia Neoaristotelica 15 (2018), 217-282.

Lanza, Lidia, and Marco Toste, "The Commentary Tradition on the Summa Theologiae", in Lanza, Lidia and Marco Toste (eds.), Summistae: The Commentary Tradition on Thomas Aquinas' Summa Theologiae from the 15th to the 17th Centuries, Leiden / Boston 2021, 3-93.

López de Goicoechea Zabala, Francisco Javier, Juan Márquez, un intelectual de su tiempo, Madrid 1996.

Machado Santos, Mariana Amélia, Manuscritos filosóficos do século XVI existentes em Lisboa: catálogo, Coimbra 1951.

Maia do Amaral, António Eugénio (ed.), Os livros em sua ordem. Para a história da Biblioteca Geral da Universidade (antes de 1513-2013), Coimbra 2014.

Mantovani, Mauro, An Deus sit (Summa Theologiae I, q. 2). Los comentarios de la "primera Escuela" de Salamanca, Salamanca 2007.

Marcocci, Giuseppe, “' ... per capillos adductos ad pillam'. Il dibattito cinquecentesco sulla validità del battesimo forzato degli ebrei in Portogallo (1496-1497)", in Prosperi, Adriano (ed.), Salvezza delle anime, disciplina dei corpi. Un seminario sulla storia del battesimo, Pisa 2006, 339-423.

Marcocci, Giuseppe, "Remembering the Forced Baptism of Jews: Law, Theology, and History in Sixteenth-Century Portugal", in García-Arenal, Mercedes and Yonatan Glazer-Eytan (eds.), Forced Conversion in Christianity, Judaism and Islam. Coercion and Faith in Premodern Iberia and Beyond, Leiden / Boston 2019, 328-353.

Martínez Fernández, Luis, Sacra doctrina y progreso dogmático en los "Reportata" inéditos de Juan de Guevara, dentro del marco de la Escuela de Salamanca, Vitoria 1967.

Maryks, Robert Aleksander, Saint Cicero and the Jesuits. The Influence of the Liberal Arts on the Adoption of Moral Probabilism, Aldershot 2008. 
O’Malley, John W., The First Jesuits, Cambridge (MA) 1993.

Olivares, Estanislao, "Francisco de Gouvea S.I. (1540-1628), Antinavarrus. Introducción y edición", in Archivo teológico granadino 27 (1964), 271-384.

Orrego Sánchez, Santiago, La actualidad del ser en la "Primera Escuela" de Salamanca. Con lecciones inéditas de Vitoria, Soto y Cano, Pamplona 2004.

Pena González, Miguel Anxo, "La Universidad de Salamanca y el control de la Teología a través de la Summa (siglos XVI-XVII)", in Salmanticensis 57 (2010), 53-84.

Pereña Vicente, Luciano, "Un nuevo manuscrito de Juan de la Peña sobre la Secunda Secundae", in Revista Española de Teología 13 (1953), 215-219.

Pozo, Cándido, "La Facoltà di Teologia del Collegio Romano nel XVI secolo", in Archivum Historiae Pontificiae 29 (1991), 17-32.

Pozo, Cándido, "Origen e historia de las facultades de teología en las universidades españolas", in Pozo, Candido, Estudios sobre historia de la teología. Volumen homenaje en su $80^{\circ}$ aniversario, Toledo 2006, 41-58.

Queirós Veloso, José Maria, A Universidade de Évora: elementos para a sua história, Lisboa 1949 .

Rabeneck, Ioannes, "De vita et scriptis Ludovici Molina", in Archivum Historicum Societatis Iesu 19 (1950), 75-145.

Reinhardt, Klaus, “Dokumentation zu Pedro Luis SJ (1538-1602)”, in Aufsätze zur portugiesischen Kulturgeschichte 3 (1963), 1-46; 4 (1966), 1-63.

Reinhardt, Klaus, Pedro Luis SJ (1538-1602) und sein Verständnis der Kontingenz, Praescienz und Praedestination. Ein Beitrag für Frühgeschichte des Molinismus, Münster 1965 .

Reinhardt, Klaus, Bibelkommentare spanischer Autoren (1500-1700). 2: Autoren A-LI, Madrid 1990.

Rodrigues, Manuel Augusto, A Cátedra de Sagrada Escritura na Universidade de Coimbra. Primeiro Século (1537-1640), Coimbra 1974.

Rodrigues, Manuel Augusto, "Relaciones académicas entre Coimbra y Salamanca: algunos casos destacados", in Rodríguez-San Pedro Bezares, Luis Enrique (ed.), Historia de la Universidad de Salamanca. Volume 3.2: Saberes y confluencias, 5 vols., Salamanca 2006, 1129-1146.

Rodrigues, Manuel Augusto, "Padres agostinhos do século XVI lentes de teologia da Universidade de Coimbra", in Rodrigues, Manuel Augusto, A Universidade de Coimbra: figuras e factos da sua história. Volume 1, 2 vols., Porto 2007, 329-339.

Rodríguez, Florencio Marcos, "Los estudios del beato Juan de Ribera en la Universidad de Salamanca", in Salmanticensis 7 (1960), 85-99.

Rosa, Teresa, História da Universidade teológica de Évora (séculos XVI a XVIII), Lisboa 2013 .

Sarmiento, Augusto, "Lecturas inéditas de F. de Vitoria: Bases para la edición crítica”, in Scripta Theologica 12 (1980), 575-592. 
Schmutz, Jacob, La querelle des possibles. Recherches philosophiques et textuelles sur la métaphysique jésuite espagnole, 1540-1767 (PhD dissertation, École pratique des hautes études, Paris; Université Libre de Bruxelles), 2 vols., Bruxelles 2003.

Silva Dias, José Sebastião, A política cultural da época de D. João III, 2 vols., Coimbra 1969. Silva Gonçalves, Nuno, "Jesuits in Portugal”, in McCoog, Thomas M.(ed.), The Mercurian Project: Forming Jesuit Culture, 1573-1580, Roma 2004, 705-744.

Soto Artuñedo, Wenceslao, La fundación del colegio de San Sebastián. Primera institución de los Jesuitas en Málaga, Málaga 2003.

Stegmüller, Friedrich, Geschichte des Molinismus 1: Neue Molinaschriften, Münster 1935. Stegmüller, Friedrich, Filosofia e teologia nas Universidades de Coimbra e Évora no século XVI, Coimbra 1959.

Taveira da Fonseca, Fernando, “A teologia na Universidade de Coimbra”, in História da universidade em Portugal 1.2: 1537-1771, Coimbra 1997.

Taveira da Fonseca, Fernando, "A imprensa da Universidade de Coimbra no período de 1537 a 1772", in Imprensa da Universidade de Coimbra. Uma história dentro da História, Coimbra 2001, 7-52.

Theiner, Johann, Die Entwicklung der Moraltheologie zur eigenständigen Disziplin, Regensburg 1970.

Toste, Marco, "The Commentaries on Aquinas's Summa Theologiae I⿳亠口冋-II ${ }^{\mathrm{ae}}$, qq. 90-108 in Sixteenth-Century Salamanca: A Study of the Extant Manuscripts", in Bulletin de Philosophie Médiévale 55 (2013), 177-218.

Toste, Marco, "Unjust Laws and Moral Obligation in the Sixteenth-Century Salamancan Commentaries on Thomas Aquinas's De legibus", in Culleton, Alfredo and Roberto Hofmeister Pich (eds.), Right and Nature in the First and Second Scholasticism. Acts of the XVIIth Annual Colloquium of the SIEPM, Porto Alegre, Brazil, 15-18 September 2010, Turnhout 2014, 93-123.

Toste, Marco, "Between Self-Preservation and Self-Sacrifice: The Debate in SixteenthCentury Scholasticism", in Lanza, Lidia and Marco Toste (eds.), Summistae: The Commentary Tradition on Thomas Aquinas' Summa Theologiae from the 15th to the 17th Centuries, Leiden / Boston 2021, 361-392.

Xavier Monteiro, António, Frei António de São Domingos e o seu pensamento teológico: sobre o pecado original, Coimbra $195^{2}$. 